\title{
Mahāsukhavajra's Padmāvatī Commentary on the Sixth Chapter of the Candamahäroṣanatantra: The Sexual Practices of a Tantric Buddhist Yogī and His Consort
}

\author{
Samuel Grimes \\ $\&$ \\ Péter-Dániel Szántó
}

\section{Introduction}

The main topic of this article is Mahāsukhavajra's commentary on the sixth chapter of the Candamahärosanatantra. To the best of our knowledge, no complete chapter of this commentary has been published so far. We present a critical edition of this text from the only available palm-leaf manuscript (without reference to the paper copies), accompanied by an annotated translation. Having realised that the text would be unintelligible without reference to the tantra, for the sake of convenience we decided to include that text too, as well as a previous translation. Since we disagree with many readings and interpretations, this can almost be viewed as a completely new translation.

A few words about how we co-authored this article. Samuel Grimes (SG) came to the Oriental Institute, University of Oxford to read for an MPhil in Classical Indian Religions. After the (much lamented) retirement of Prof. Alexis Sanderson, PéterDániel Szántó (PDSz) suggested several topics for the thesis. SG chose Mahāsukhavajra's commentary, the Padmāvatī, and we started reading the text together. An edition and translation of the present chapter eventually materialised as SG's MPhil thesis, but the present article adds much new material and improves on the readings significantly. After having spent a year in Nepal, SG was accepted to read for a $\mathrm{PhD}$ at the University of Virginia, eventually hoping to publish the entire commentary with a translation and a more in-depth study. This article is therefore a kind of preview of that work; we therefore decided to keep the introduction as short as possible.

\subsection{The Caṇdamahāroṣaṇatantra}

The first Western scholar to briefly describe the Candamahāroṣanatantra was Alexander Csoma de Körös (1836-1839: 368). He did not of course have access to the original Sanskrit, but of the Tibetan translation he says: "This is an excellent tantra, and in a good and easy translation." The first Westerner to have read the Sanskrit text was most likely Brian H. Hodgson. ${ }^{1}$ He procured at least three copies of the text, of these he sent two to England; they can still be accessed at the Royal Asiatic Society and the Bodleian Library respectively. The sixteenth chapter of the text based on three manuscripts was published by Louis de la Vallée Poussin (1897). The first partial edition of the text, the first eight chapters out of twenty-five, was undertaken by Christopher S. George in his doctoral thesis (1971). An updated

\footnotetext{
${ }^{1}$ Also cf. Amrtānanda's documents prepared for Hodgson, which copy freely from the tantra, Szántó 2012, I: 194.
} 
version of this appeared in publication in 1974, a pioneering work, which is still the cornerstone of Candamahāroṣana studies. Full translations exist in both German (Gäng 1981) and French (Chazot, Chazot \& Delamotte 2015) ${ }^{2}$, which, although very useful, can hardly be described as scholarly renderings. A full critical edition is yet to appear in print. Recently, Wiesiek Mical has produced a draft critical edition of the full text; we occasionally refer to this work with much gratitude to its author for sending an early version. Mical, aided by James Gentry and Andreas Doctor, has also produced a full English translation, which has appeared very recently on the website of the 84,000 Project (DhTC 2016) along with the Sanskrit. Unfortunately, we became aware of this too late to engage with it comprehensively.

The historical aetiology of the text is also a matter for future investigation. Its importance is beyond question: as mentioned by George (1974: 9), the work enjoys great popularity in Nepal, where the eponymous deity "is worshipped daily in public and in household shrines of many Newar families." Testimony to its popularity throughout the ages is the large number of surviving manuscripts. George speculates that "as many as one hundred fifty MSS of this text were copied throughout its history," but he does not share his reasons for stating this. At any rate, he had access to no less than sixteen witnesses spanning more than six centuries and even so the list is not exhaustive; for example, he missed Rahul Sankrtyayan's photographs of an old palm-leaf manuscript found in Tibet (Mical's Gt), the Bodleian manuscript (Hodgson 2 ), and perhaps as many as a hundred more in Nepal. It would seem that there are no non-Nepalese witnesses of the text, and that there are no traces of Candamahāroṣana worship in other places on the Indian Subcontinent. ${ }^{3}$ Nor is there any hard textual evidence for the tantra's existence before the 13th century. George (1974: 5) found it likely that this date can be pushed back to about $1100 \mathrm{CE}$, but with palpable hesitation he settled on the date of the commentary's (palm-leaf) Ms as the terminus ante quem (1297 CE, see below). At the same time, he seriously underestimated the antiquity of the Tibetan translation (1974: 11-12). Since he could not identify the translators, Ratnaśrī and Grags pa rgyal mtshan, he preferred to err on the side of caution and said: "Since the Derge edition was printed in the early 18th century, our translation is certainly prior to this date." The duo was identified by van der Kuijp (2009: 29) and the possible dates narrowed down to 1293 or $1305 \mathrm{CE}$, with a strong preference for the former. This takes us back only four years. ${ }^{4}$ While fully aware that absence of evidence is not evidence of absence, these facts lead us to formulate the hypothesis

\footnotetext{
${ }^{2}$ In actual fact, this is an indirect translation from Newar by Delamotte from a manuscript by Ratna Bāhādur Vajrācārya (1892-1956), which was transmitted to Dharma Guruju (1898-1990), a man of peculiar status and reputation in Newar society.

${ }^{3}$ We are aware that two statues have been identified as 'Mahācaṇdaroṣaṇa' in India proper: one in Cave 10 in Panhale, and one at Ratnagiri (Deshpande 1984: 46-50). As we point out immediately below, the cult of the deity Acala is old and widespread, and therefore these two statues cannot be used as evidence for the existence of the tantra in these two locations.

${ }^{4}$ We must disagree with DhTC 2016: I.6, who date the translation to 1209 or 1197 CE. The Tibetan is not the Sa skya patriarch, but the translator from Yar klung. The same paragraph claims that the oldest witness of the tantra is from $1380 \mathrm{CE}$, but this is an error, as the date is George's estimate.
} 
that the text is a comparatively late Nepalese production. ${ }^{5}$ However, we hasten to point out that the deity of which Caṇ̣amahāroșaṇa is a sort of upgrade, Acala, is indeed very old and commanding a widespread cult as far as Japan, where he is known as Fudō Myō-ō. ${ }^{6}$

The tantra is a careful, thoughtful, and rather original composition, but some of its antecedents are clear. There are many echoes of the Hevajratantra, not to mention that scripture's teaching on the Four Blisses, which is important for this text. There are also traces of the Catuspițatantra, as pointed out by Szántó 2012, I: 211 \& II: 16-18. We identify an incorporation from the Cittaviśuddhiprakarana just below (ad 6.80-81). A careful study will doubtless identify many more sources inspiring the nameless author (authors?) of the Candamahāroșanatantra. Compared to other items of the genre, this tantra is well organised and relatively clear. Its primary charm lies in its outspokenness, but this quality may have hampered its study. As George points out (1974: 3), de la Vallée Poussin intended to publish an edition at one point, but this study never appeared. George concludes: "It seems clear that the intellectual climate for the investigation of such texts was much less favorable at his time than it is today." We hope that we still live in such an intellectually tolerant environment.

\subsection{The Padmāvatīnāmapañjikā of Mahāsukhavajra}

The Padmāvatī, as we shall refer to it henceforth, is the only known commentary of the Candamahāroṣanatantra in Sanskrit. It was not translated into Tibetan and we have only one, as we shall show below, now fragmentary, palm-leaf manuscript. We are aware of five further copies. Of these, currently we have access to two, which can be shown conclusively to be paper apographs.

\subsubsection{The Palm-leaf Manuscript}

The first to report the existence of and describe this rare source was Hara Prasad Śāstri (1915: 92-94), giving fairly copious extracts of the incipit and the explicit, as well as a transcript of the colophon. These extracts were transcribed and translated (we regret to say: inadequately) in Hartzell 2002: 101-104, 161-162. George (1974: 6) essentially copied the catalogue's description and sporadically mentioned the views of the commentator in the notes to his translation. We have the feeling that his study of the commentary was not exhaustive and, somewhat surprisingly, he never mentions the readings of the lemmata in his critical notes, in spite of the fact that this is by far the earliest textual evidence, even if fragmentary. George's earliest manuscript of the müla is estimated by him to date from ca. $1380 \mathrm{CE}$, whereas the date of the Padmāvati Ms. is 1297 CE (Tuesday, March 19th, as verified by Petech 1984: 98).

The manuscript in its present state consists of 33 consecutively numbered folios. A superficial examination would determine that it is complete: there is a beginning, there is an end, and there are no missing folios. But this is not so. It is clear to us that the numeration, which is on the right margin, is secondary, that is to say, not the

\footnotetext{
${ }^{5}$ This suspicion was first voiced to PDSz by Harunaga Isaacson, to whom many thanks. We note that DhTC 2016: I.2-3 came to a similar conclusion.

${ }^{6}$ Also cf. DhTC 2016: I.5, citing Harunaga Isaacson's list of several old tantric scriptures in which Acala figures.
} 
scribe's. Folio 12 is definitely out of place and some text was lost between this and the next two leaves. This matter awaits a more thorough investigation. Conclusive evidence is provided by folios 30 and 31 . The former contains text commenting on the 15 th chapter and the latter begins with the commentary to chapter 19 . The conclusion is inevitable: at some point several leaves were lost from the manuscript, and someone re-numerated it. With this in mind, we re-examined the left margin and did indeed discover occasional faint traces of numbers and letter-numerals. Unfortunately, the eraser did a pretty fine job. X-ray fluorescence imaging could no doubt reveal this original set. For now, we must be content with using the secondary numeration in our references. As an aside, we should note that, somewhat curiously, the same process seems to have happened to George's ms. A (1974: 6).

Hara Prasad Śāstri calls the script 'Newári', whereas George 'Newārī (Old Bhujimola)'. Given the sad state of Nepalese and East Indian palaeographical studies, we are very hesitant. We note, however, that the scribe uses not the sirorekha $e$, but the prșthamattra $e$ throughout, and his $p a$ is more reminiscent of a Bengali/Maithili type. We cannot say with certainty that this is not the hand of an East Indian. That said, the manuscript was doubtless produced in Nepal (as the dating uses the Nepālasamvat, and mentions the reign of Anantamalla), but perhaps not necessarily by a Nepalese.

We do not have any conclusive evidence about the existence of other, independent copies of the Padmāvatī. SG was told that an exemplar is kept in a private collection in Nepal, but was not allowed to see it. We suspect that this is an apograph of the palm-leaf manuscript, because the owner mentioned the same date, $1297 \mathrm{CE}^{7}$ The two other mss. we have access to are from the Kyoto University Library (no. 38) and the IASWR collection (MBB-I-76, now in the University of Virginia Library, still not catalogued). These two are certainly apographs, but they were prepared before the folio loss in the palm-leaf manuscript. We cannot say anything at this point about the Baroda (Oriental Institute no. 13274) or the Nagoya copy (Buddhist Library Takaoka $\mathrm{Ka} 4-2)$.

\subsubsection{The Author}

We do not know much about the author, Mahāsukhavajra. The colophon (Ms 33v) styles him a 'great scholar' (mahapandita ${ }^{\circ}$ ). The final verse (Ms 33r) reveals only that he wrote his commentary by the command of his guru $(k r t v \bar{a}$... pañjim guror a $\bar{j} \tilde{n} a y \bar{a})$. Hardly conclusive evidence, but it is perhaps worth mentioning that the paradigmatic city for him seems to have been Pāțalīputra (Ms 31r: nagaram iti pāțalīputrādikam). We hope that a thorough investigation of realia in his commentary (materia medica, currencies, etc.) will yield better ideas about his provenance. The work is relatively rich in quotations; we expect to formulate better ideas about the possible timeframe this textual pool may reflect after a complete review. For now we must work with the assumption that he was a Nepalese scholar active in the 13th century CE. SG was told by an informant in Nepal that Mahāsukhavajra was also the author of the

Candamahâroṣanatantra itself, and composed the texts concomitantly at the order of the king Anantamalla, who is mentioned in the Ms colophon. This claim is tentative:

\footnotetext{
${ }^{7}$ An apograph is also mentioned in DhTC 2016: I.8. We are not entirely sure what this refers to, perhaps the Baroda copy.
} 
it may be a remnant of a largely forgotten Vajrācārya tradition, but it could also be a personal impression.

\subsection{Some Background for Chapter 6}

By the time the yogĩ reaches in his spiritual career the matters taught in chapter 6 , he will have undergone the following. First, initiation (abhișekah). In order to gain this, he is introduced to the pantheon of the deities (mandalam), a diagram drawn with coloured powders, which is described in chapter 2 . The initiation ritual itself is described in chapter 3 . The first five initiations are those of Water $\left(u d a k a^{\circ}\right)$, Tiara $\left(m a k u t a^{\circ} / m u k u t a^{\circ}\right)$, Sword $\left(k h a d g a^{\circ}\right)$, Noose $\left(p \bar{a} s^{\circ} a^{\circ}\right)$, and Name (nama $\left.a^{\circ}\right)$. This set is a little unusual, since the third and fourth are named after the main implements of the deity and not the standard ones, named after the general implements of the tantric Buddhist initiate, the Sceptre $\left(\right.$ vajra $\left.^{\circ}\right)$ and the Bell (ghant $\left.\bar{a}^{\circ}\right)$. A further distinctive feature is that women are specified to receive the Vermilion $\left(\operatorname{sind} \bar{u} r a^{\circ}\right)$ Initiation instead of that of the Tiara. The Secret $\left(g u h y a^{\circ}\right)$ Initiation follows: here the master copulates with a consort and the initiand is called in to consume the sexual fluids saved in cupped leaves. ${ }^{8}$ As an intermezzo, the initiand is called to secrecy threatened by a sword, is blindfolded, and is made to cast a flower on the diagram. Then the blindfold is removed and he is shown the mandalam. This is again unusual, since these procedures are normally performed before the Water Initiation, and it is not a sword, but a vajra-sceptre with which he is threatened. In the Wisdom (prajñ $\bar{a}^{\circ}$ ) Initiation it is the initiand who unites with the consort, who is specifically stated to be the same as the one before. He is to experience the Four Blisses as explained to him by the guru beforehand (on these, see our note to 6.192-196). Once finished, he throws a feast for his fellow initiates (ganacakram). ${ }^{9}$ The text says that for women, this initiation is called that of Means (up $\bar{a} y a^{\circ}$ ), another unique feature of this text. With the initiation successfully completed, the $y o g \bar{l}$ has now gained the right and duty to practice. This is detailed in chapter 4 and more or less amounts to what is usually called the Stage of Generation (utpattikramah). The main point is to create and maintain identity with the deity. The next chapter teaches various mantras. Once identity with the deity has been mastered, the yogi becomes able to practice the Perfected Stage (nispannakramah/utpannakramah), and this is what the question of the Goddess refers to.

Although our two texts are not unique in their treatment of sexual practices, chapter 6 and its commentary are special, because we do not find such information presented with this kind of clarity and a luxury of details elsewhere. Mahāsukhavajra severely attacks those who would think that the sexual imagery is merely symbolic, so he is well aware of tantric initiates who treat such practices in a subliminal and non-literal way. The vehemence of his tone suggests to us that he may have lived at a time when

\footnotetext{
${ }^{8}$ Although the text specifically prescribes instructions for the initiation of women, it is ambiguous as to what they are to do in the guhyäbhiṣekah. The male initiand's task is clear: he brings a girl, with whom the guru, and then himself, copulate. The likeliest scenario is that the female initiand herself copulates with the guru, and this is considered her Secret Initiation. However, this is only a speculation on the part of the authors.

${ }^{9}$ The tantra does not contain ritual prescriptions for the ganacakram. Also note that the Fourth Initiation (caturthäbhișekah) is not mentioned.
} 
those with antinomian interpretations of the tantras were being pushed out by those taking a symbolic approach, perhaps as a compromise to social norms. If this was indeed the case, but we should stress that this only our impression, Mahāsukhavajra may have been a 'purist' attempting to revive and maintain disappearing practices. We hope that more resources will come to light to reveal the socio-historical context.

Finally, we would like to acknowledge and thank several people for their kind help: the Warden and Fellows of All Souls College, the staff of the National Archives in Kathmandu, the organisers and participants of the SOAS Sanskrit Reading Room (May and October 2017), the organisers and participants of the Vikramaśilla Workshop in Tokyo (November 2017), Csaba Dezső, Harunaga Isaacson, Berthe Jansen, Christopher V. Jones, Kei Kataoka, Jonathan Katz, Kenichi Kuranishi, Izumi Miyazaki, Nawang Thokmey, and Richard Widdess. 


\section{Sanskrit text}

\section{Note on the Apparatus:}

Our only witness (marked Ms) is National Archives, Kathmandu, Nepal 3-402/vi. bauddhatantra 19. This manuscript was first archived by the Nepal-German Manuscript Preservation Project, under reel no. B 31/7. We read colour images of the original, which were commissioned by SG. The punctuation is our own, as is the regularisation of sandhi and avagrahas. We have implemented the standardisations usual for Nepalese/East Indian manuscripts: we distinguish between $v$ and $b$, we degeminate after repha (e.g. sarva for sarvva), geminate where appropriate (e.g. sattva for satva), we do not always note confusion of sibilants $(\dot{s}, s, s)$, we standardise homorganic nasals, etc. A + sign with spaces on both sides denotes a full akșara missing (e.g. the leaf is torn) or deemed illegible (effaced); A + sign without space on either or both sides denotes a partial loss of an akșara. We only mark folio changes; here $\mathrm{r}$ stands for recto, $\mathrm{v}$ for verso. We occasionally mark scribal or readers' corrections: p.c. stands for post correctionem, a.c. for ante correctionem, i.e. after and before correction respectively. Our critical notes are corrections marked by corr. (in case of minor matters such as an 'invisible' virāma), emendations are marked by em. (in case of more serious mistakes such as an omitted akșara), and conjectures are marked by conj. (which are for the most part emendations about which we feel somewhat hesitant). We first print the mūla as given in George's edition in bold; this is followed by his numeration in square brackets: note that George counts lines, not verses. We marked the lemmata in bold. Bracketed exclamation marks are placed in the müla if we note a dissonance with the commentary or a reading we consider mistaken or not chosen well. These are explained in the notes to the translation. We skip two sections of the müla, which are irrelevant for our discussion. We do not capitalise technical terms or proper names in the edition. We decided not to use the testimony of the two available apographs; they add nothing new textually as the palmleaf manuscript was already damaged at the time of their preparation.

\section{atha bhagavatī prajñāpāramitā bhagavantạ̣ gāọham ālingya padmena vajragharṣaṇạ̣ kṛtvā prāha || [6.1-2]}

athetyādi | prajñāpāramiteti dveșavajrī | sānvayeyaṃ saṃjñā | prakṛ̦țạ̣ jñānaṃ ${ }^{10}$ prajñā, sahajānanda ${ }^{11}$ jñānam $\mid$ pāram prakarṣam svarasapravṛttam itā gatā prāpteti yāvat | prajñāyāḥ pāram itā ${ }^{12}$ prajñāpāramitā, sahajānandajñānakāraṇatvāat ${ }^{13}++++$ + ḥ | gāọham iti ni[16v]rbharam yathā bhavati ${ }^{14} \mid$

\section{niṣpannakramayogena bhāvanā kīdṛśī bhavet | yoginīnāṃ hitārthāya pṛcchitaṃ saphalīkuru || [6.3-4]}

niṣpannetyādi | ayam abhiprāyah | pū + + kṣaṇā hi bhāvanotpattikramāpekṣayā jñāte

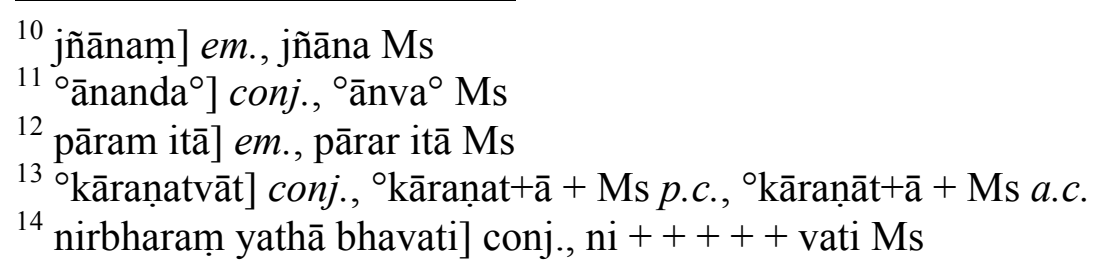


(?) vi +++++ nnakrame ++++++ kartavyeti ${ }^{15}$ bhāvah |

atha bhagavān āha $\|$

niṣpannakramayogastho yogī yogaikatatparạ̣ |

bhāvayed ekacittena mama rūpam aharniśam || [6.5-7]

niṣpannakrama utpannakramạ̣ | ekacittenetyādi | ayam arthạ̣ |

pūrvoktamaitryādibhāvanākramanirapekṣo yogī

jhatityākārayogenaikacittenādvitīyacittena kṛṣnācalādi ${ }^{16}$ rūpeṇātmānam bhāvayet |

svastriyam (see 6.8) ca dveșavajryādirūpeṇeti bhāvah | aharniśam iti ${ }^{17}$ rātriṃdinam | kṣaṇam apy ${ }^{18}$ anyacittena na tișṭhed ity arthạ |

kalpayet svastriyam tāvat tava rūpeṇa nirbharām |

gāọhenaivātiyogena yathaiva sphuțatāṃ vrajet || [6.8-9]

sphuṭatām iti tadākāratadahaṃkārayoh pravyaktatām | etac ca

sādaranirantaradīrghakālābhyāsaị̣ sampadyate | tathā coktam-

bhūtaṃ vā yadi vābhūtaṃ yad yad evātibhāvyate |

bhāvanābalaniṣpattau tat sphuțākalpadhīphalam ${ }^{19} \|$

abhyāsayogena bhavanti puṃsāṃ bhūtāny abhūtāni puraḥsthitāni |

kāmākulānām iva ramyarāmāśs ${ }^{20}$ cittānuyātā nanu yogayuktị̣ \|

mātarạ̣ duhitarạ̣ cāpi bhaginīṃ bhāgineyikām |

anyāṃ ca jñātinīṃ sarvāṃ ḍ̣ombinīṃ brāhmaṇịm tathā || [6.10-11]

mātaram ityādi | mātrādiprajñām apatitayauvanām eva gṛhnīyāt | prāyeṇa kila purușāṇāṃ mano yasminn ${ }^{21}$ vișaya evārpyate ${ }^{22}$ tatraivātiśayena pravartate | pravartitam api mano lokabhayato vyāvartate taih | vyāvṛttikṛtam tu tīvraduhkkham te 'nubhavanti | dukhāc cetaso bhavati vikṣepaḥ | tato 'pi samādhānābhāvah | samādhānābhāvāat ${ }^{23}$ tu na mahāmudrāsiddhir bhavatīti ${ }^{24}$ |

na cādharmah sambhāvyate, svaparāpakārābhāvāt | na ca ++++ saṃ ++++++++ ++ , mahāsukhānubhavarūpatvāt | etad eva svaparayor arthakaraṇam | tathā ca-

[17r] samyak svaparayor artham kurvan punyaṃ samarjati ${ }^{25}$ |

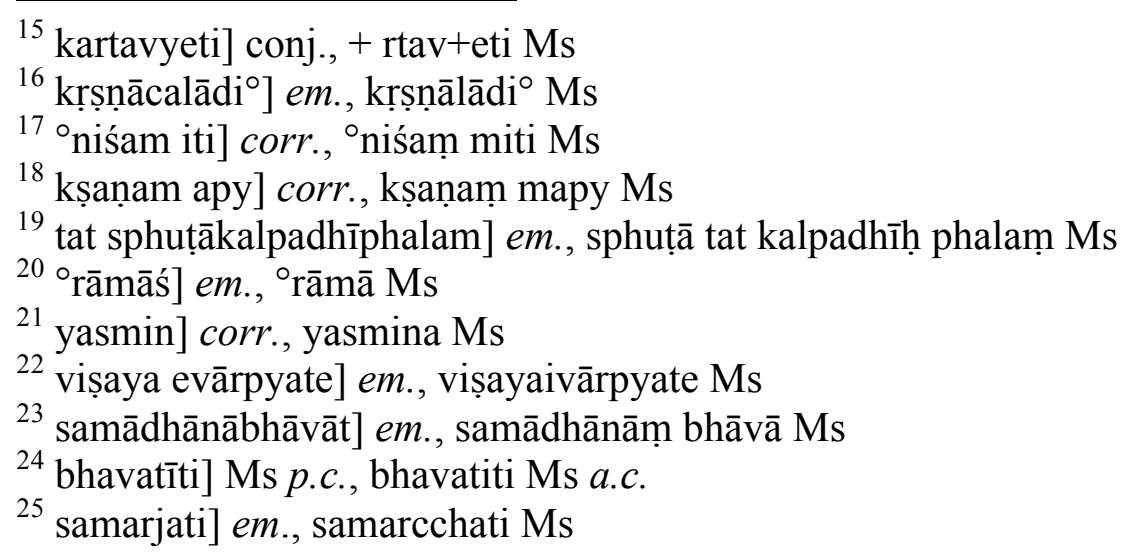


ato viparyayāt pāpaṃ sukhaduḥhaphalaṃ ${ }^{26}$ tayoḥ \|

na ca prajñāviśeșataḥ pāpam, tantrāntaravirodhād eva | tathā ca—

mātā bhaginī bhāgineyikā

ityādi |

yatra tu mātrādiśabdena cakșurādy uktam tatra tv abhavyasattvebhyas tattvaṃ gopitam | anyathā cakṣurādiśabdān apahāya lokaviruddhamātrādiśabdā ye kṛtās te conmattapralāpā eva vyaktam upalakșyanta iti |

tatra mātā janan̄in, sapatnamātā, mātṛșvasā ${ }^{27}$, ācāryabhāryā ceti | duhitā janyā, bhrātṛduhitā, saṃgrhīta ${ }^{28}$ saduhitṛkastrīpūrvaduhitā, ācāryaduhitā ceti | bhagin̄̄ sālohitā mātṛ̦vașr ${ }^{29}$ duhitā, ācāryaduhitā ceti | āsām eva sutā bhāgineyikāa | caturvidhābhyo 'nyāḥ ${ }^{30}$ sarvā eva vakṣyamāṇalakṣaṇāḥ ${ }^{31}$ |

caṇụālīṃ naṭakīṃ caiva rajakīṃ rūpajīvikām (!) | vratinīṃ yoginīm caiva tathā kāpālinīṃ punạ̣ || [6.12-13]

rūpājīvikām ity agṛhītapaṇyāṃ veśyām |

anyāṃ ceti yathāprāptāṃ strīrūpeṇa susaṃsthitām | sevayet suvidhānena yathā bhedo na jāyate || [6.14-15]

yadi bhedạ̣ syāt, tadā kiṃ syād ity āha — bhede tv ityādi |

bhede tu kupitaś caṇḍaroṣaṇo hanti sādhakam | avīcau pātayet taṃ ca khạ̣gapāśena bhīṣayan || neha loke bhavet siddhih paraloke tathaiva ca | tasmāc ca guptam atyantam kartavyam nāpi gocaram || ḍākinīmantravad gopyạ̣ cạ̣ḍaroṣaṇasādhanam | [6.16-20]

nanu yady evam kimartham tarhy uktam mahānartha ${ }^{32}$ janakam etat sarvam ity āhaatyantetyādi |

abhyanta(!)kāminām arthe mayā buddhena bhāṣitam || [6.21]

ayam arthạ̣ | rāganayo 'yam, rāgaś cotpanno na parihartavya eva |

\footnotetext{
${ }^{26}$ Harunaga Isaacson suggested three possible emendations: sukhaduhkham phalaṃ/sukhaduhkhe phalaṃ/sukhaduhkhe phale.

${ }^{27}$ mātṛșvasā] corr., mātṛ́śvasā Ms

${ }^{28}$ samgṛhīta $^{\circ}$ em., samgrahīta ${ }^{\circ} \mathrm{Ms}$

$29{ }^{\circ}$ ṣvasrọ ${ }^{\circ}$ em., ${ }^{\circ}$ śvasrū ${ }^{\circ} \mathrm{Ms}$

30 'nyāḥ] em., 'nyā Ms

31 vakṣyamāṇalakṣaṇāḥ] em., vakṣamāṇalakṣaṇā Ms

${ }^{32}$ mahānartha ${ }^{\circ}$ ] em., mahānanva ${ }^{\circ} \mathrm{Ms}$
} 
yadi vā sākșān naitac ${ }^{33}$ chakyate, tadā tatpratikṛtiṃ dārvādinirmitāṃ pațalikhitāṃ vā sevayed iti $\mid$

etac ca viviktasthāna eva yujyata ity āha — mano’nvityādi |

mano 'nukūlake (!) deśe sarvopadravavarjite |

pracchanne tāṃ samādāya svacetoramyakāminīm || [6.22-23]

pracchanna iti bhittipațalakapāṭādyāvṛte | samādāyeti ${ }^{34}$ gṛhītvā |

svacetoramyakāminīm iti tāsāṃ madhye yathāmanovāñchitām |

buddho 'hạ̣ cācalaḥ siddhạ̣ prajñāpāramitā priyā |

bhāvayet svasvarūpeṇa gāọhena cetasā sudhīḥ || [6.24-25]

svasvarūpeṇeti pūrvoktarūpam eva spașțayati | ayam arthạ̣ |

utpattikramakṛtadevatā[17v]dvāreṇa

varṇasaṃsthāna ${ }^{35}$ khaḍgakartry ${ }^{36}$ ādikaracaraṇavinyāsādiyuktena na bhāvayet, kiṃ tu yenaiva rūpeṇa svasya svasya varṇasaṃsthānādikam prakṛtisiddham, tenaiva ${ }^{37}$ rūpeṇa $^{2}$ bhāvayed iti |

nirjanaṃ cāśramạ̣ kṛtvā yathālabdhānnavastukạ̣ (!) |

bhāvayen nirbharạ̣ dvābhyām anyonyadvandvayogatạ̣ || [6.26-27]

yathetyādi | yathāprāptabhaktavasanābhyāṃ kaṃ sukhaṃ yasya sa tathā | idaṃ bhaktādi bhadram idam neti na kuryād ity arthạ | dvandvayoga ālinganādiyogaḥ |

striyam pratyakṣatạ̣ kṛtvā sammukhe copaveśya hi | dvābhyām anyonyarāgeṇa gāụham anyonyam īkṣayet || tato dṛștisukhạ̣ dhyāyan tiṣthed ekāgramānasaḥ | tayā tatraiva vaktavyạ̣ sukhottejaḥkaram vacạ̣ || [6.28-31]

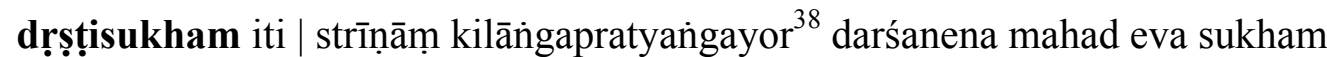
utpadyate $\mid$ tato yayaiva mudrayā tat ${ }^{39}$ sukham utpannaṃ tayaiva mudrayā kāșțhavan niścalībhūya tat ${ }^{40}$ sukham cintayams ${ }^{41}$ tiṣthet katipayakṣaṇam ity arthaḥ | tatạ̣ śabdasukhạ̣ bhāvayet | tayetyādi | sukhottejạ̣karam iti pūrvotpannasukham adhikạ̣ karotīty arthạ̣ |

tvaṃ me putro 'si bhartāsi tvaṃ me bhrātā pitā matạ̣ | tavāhạ̣ janan̄̄ bhāryā bhagin̄̄ bhāgineyikā || saptabhị̣ puruṣair dāsas tvaṃ me khețasacețakạ̣ (!)|

${ }^{33}$ naitac] corr., netac Ms

${ }^{34}$ samādāyeti] em., samādāpeti Ms

35 ○ samısthāna ${ }^{\circ}$ ] em., ${ }^{\circ}$ samusthāne Ms

${ }^{36}{ }^{\circ} \mathrm{kartry}^{\circ}$ ] corr., ${ }^{\circ} \mathrm{kartty}^{\circ} \mathrm{Ms}$

${ }^{37}$ prakrtisiddham, tenaiva] conj., prakrti +++ naiva Ms

38 o pratyangayor] em., ${ }^{\circ}$ pratyangayo $\mathrm{Ms}$

${ }^{39}$ tat $^{\circ}$ ] corr., tata $\mathrm{Ms}$

${ }^{40}$ tat $\left.^{\circ}\right]$ corr., tata $\mathrm{Ms}$

${ }^{41}$ cintayams] em., cintaya Ms 
tvaṃ me putro 'sītyādiślokadvayaṃ kākasvareṇa kahu(?)rāgeṇa strī paṭhet puruṣạ̣ paśyantīti | tatạ pūrvakrameṇaiva tadutpannasukhạ̣ katipayakṣaṇaṃ vicintya tasyā bhaktiṃ kuryāt |

patec (!) caraṇayos tasyā nirbharam sampuṭāñjaliḥ |

vadet tatredṛ́śạ vākyaṃ sukhottejạ̣karạ̣ param || [6.36-37]

patec cetyādi | nirbharạ̣ yathā bhavati |

tvaṃ me mātāpitur (!) bhāryā tvaṃ me ca bhāgineyikā |

bhaginīputrabhāryā (!) ca tvạ̣ svasā (!) tvạ̣ ca māmikā ||

tavāhaṃ sarvathā dāsas tīkṣnabhaktiparāyaṇạ̣ |

paśya māṃ kṛpayā mātạ̣ snehadṛ̣̦ținirīkṣạ̣aị̣ || [6.38-41]

tvam $^{42}$ me mātetyādiślokadvayaṃ pūrvavad yogī pațhet | svarābhāvāt tu ${ }^{43}$ sarvatra lālityena pāṭhạ̣ kartavyạ̣ | bhrātrādimātrādiśabdās tu (see 6.32 and 6.38)

sukhottejakatvenoktā iti |

tataḥ sā puruṣaṃ śliṣțā (!) cumbayitvā muhur muhuḥ |

dadāti tryakṣarạ̣ maste vaktre vaktrarasam madhu || [6.42-43]

tryakșaram iti samadhya ${ }^{44}$ suṣiramuștyabhinayam | vaktrarasạ̣ śleșmapiṇ̣am saśabdakaṇṭhajanitam | tad eva madhv iva, madhusukhajanakatvāt |

padmạ̣ coṣāpayet tasya darśayen netravibhramam (!)|

vaktre ca carcitam dattvā kucena pị̣̄ayed hṛdam (!) || [6.44-45]

padmam iti bhagam | coṣāpayed iti yogiśiro yoginī hastam ${ }^{45}$ ākṛsyaa svapadme nipātayet | yāvac cūṣaṇakriyāniṣpattiḥ syāt tāvad yogin̄̄ yogiśirasi kṣaṇaṃ kṣaṇaṃ vilambya tryakșaram dadyāt | tatas tadananta[18r] ram yogiśira utthāpya yogin̄i netrabhramạ̣ kațākṣaṃ dadyāt |

sammukhạ̣ tanmukhạ̣ dṛṣțā nakhạ̣ dattvā cittālaye (!) |

vadet tasyedṛ́saṃ vākyaṃ bhakṣa vairocanaṃ mama || [6.46-47]

tato yogin̄̄ yoginam uttānena pātayet | tatas tanmukhe gudapadmam arpya

yonipadmaṃ ca tryakșarapūrvakaṃ bhakșa vairocanam ityādikạ̣ vadet | yathārucy $\bar{a}^{\text {śu }}{ }^{46}$ pradadyād iti | vairocanam gūtham |

pibākṣobhyajalaṃ putra sapitrā dāsako bhava |

tava gosvāminī cāhạ̣ mātā rājakūlìty (!) api || [6.48-49]

\footnotetext{
42 tvam] em., tva Ms

${ }^{43}$ tu] em., ta Ms

${ }^{44}$ samadhya $^{\circ}$ ] conj., madhya ${ }^{\circ} \mathrm{Ms}$

${ }^{45}$ hastam] em., hastām Ms

${ }^{46}$ yathārucy āśu] conj., yathārūvyā Ms
} 
akṣobhyajalam mūtram | yogy api tat sarvaṃ sādaraṃ ${ }^{47}$ gṛnan niśceștīibhūya sukham eva cintayet | tataḥ sā punas tam utthāpya sapitretyādikaṃ vadet |

madīyạ̣ carạ̣aṃ gaccha śaraṇaṃ vatsa nirantaram |

mayā samvardhito yasmāt tvam ānarghyam upāgatạ̣ || [6.50-51]

mayetyādi | mayeti mātṛūịiṇyā bālāvasthāyāṃ payodharadugdhādinā paripālitaḥ | ānarghyam amūlyam | viśișțarūpatvād ity āśayaḥ |

kṛtajño bhava bho vatsa dehi me vajrajam sukham |

tridalạ̣ pañkajạ̣ paśya madhye (!) kiñjalkabhūṣitam || [6.52-53]

kṛtam upakāraṃ jānātīti kṛtajñạ̣ | ayam abhiprāyaḥ | mayā paripālanena tavopakāraḥ kṛtaḥ, tvam apīdānīm pratyupakāraṃ kurv iti | vajrajam iti vajrạ̣ lingam, tena jātam | vajrāsphālanajātam ity arthạ̣ | tridalaṃ trikoṇam | madhyetyādi | madhye

kiñjalkena māṃsa ${ }^{48}$ vartikāsamūhena bhūṣitam |

aho sukhāvatīkṣetraṃ raktabuddhopaśobhitam |

rāgiṇāṃ sukhadạ̣ śāntạ̣ sarvakalpavivarjitam || [6.54-55]

aho iti sukhābhivyaktau | sukham avati rakșatīti sukhāvatī, saiva kṣetram sthānam | raktam śoṇitam, sa eva buddhaḥ, tenopaśobhitam | bāhyasukhāvatîkșetram apy ${ }^{49}$ amitābhaśobhitạ̣ bhavatīty arthạ̣ | sarvakalpo grāhyagrāhakagrahaṇavikalpaḥ, tena varjitam |

mām uttānena sampātya rāgavihvalamānasām |

skandhe pādayugạ̣ dattvā mamādhordhvạ̣ nirīkṣaya || [6.56-57]

skandha iti grīvāpārśvadvaye | adho bhagam | ūrdhvạ̣ mukham |

sphuradvajram tatạ̣ padmamadhyarandhre praveśaya |

dehi dhāpasahasrạ̣ tvaṃ lakṣya(!)koṭim athārbudam ||

madīye tridale padme māṃsavartisamanvite | [6.58-60]

sphuradvajram stabdhalinggam | dhāpasahasram dhāpasya kațicālanāghātasya sahasram bahutvāt, na tu saṃkhyākṛtam | evaṃ lakṣādikam api boddhavyam iti |

svavajrạ̣ tatra prakṣipya sukhaiś cittạ̣ prapūjaya \|

vāyu vāyu supadmạ̣ me sārāt sāram anuttaram |

vajrasyāgreṇa sambuddhạ̣ raktạ̣ (!) bandhūkasaṃnibham || [6.61-63]

vāyu vāyv iti praśaṃsayā ${ }^{50}$ hlādaṃ janayati | sāraḥ sukhādikam ${ }^{51}$, tasmād api sāram mahāsukhatvāt |

\footnotetext{
${ }^{47}$ sādaraṃ] em., sāradam Ms

${ }^{48}$ māmsa $^{\circ}$ ] em., mātsa ${ }^{\circ} \mathrm{Ms}$

$49{ }^{\circ} \mathrm{kssetram}$ apy] corr., ${ }^{\circ} \mathrm{kṣetram} \mathrm{mapy} \mathrm{Ms}$

${ }^{50}$ praśamsayā $\left.\bar{a}^{\circ}\right]$ corr., prasamśayā ${ }^{\circ} \mathrm{Ms}$

${ }^{51}$ sārah sukhādikam] conj., sāro mukhādikaṃ Ms
} 
bruvantīm iti tāṃ dhyāyan stabdhībhūyaikacetasā |

bhāvayet tajjakaṃ saukhyaṃ niścalo gāọhacittatạ̣ \|

tasmai (!) pratyuttaram dadyād vilamba tvạ̣ priye kṣaṇam |

yāvat strīdehagạ̣ rūpạ̣ kṣaṇamātrạ̣ vicintaye || [6.64-67]

strīm ekāṃ jananīṃ khalu trijagatāṃ satsaukhyadātrīṃ śivāṃ

vidveșād iha nindayanti mukharā ye pāpakarmasthitạ |

te tenaiva durāvagāhanarake raudre sadā duḥkhitāḥ

krandanto bahuvahnidagdhavapuṣas tiṣthanti kalpatrayam || [6.68-71]

[18v] jananīm iti sukhasya jananāt | śivāṃ kalyāṇām | kathạ̣ strīnindayā narakagamanam bhavatīti ced ucyate - aihikasukhasya jananyah kila striyah, pāralaukika ${ }^{52}$ sukhasya cāta eva paramopakārinyo ${ }^{53}$ buddhajananyah

prajñāpāramitāsvarūpiṇyạ̣ | ata ${ }^{54}$ evāsām nin nayā mahad apunyaṃ ${ }^{55}$ syāt | tato narakagatir bhavati | yaḥ punạ̣ strīnindayānyatra dharmo deśitaḥ, sa punar laukika ${ }^{56}$ kāminīrūpamātreṇābhavyasattvasya, $\mathrm{na}^{57}$ tu lokottarakāminīprajñāpāramitādirūpeṇa bhavyasattvasyeti | na cābhavyasattvo laukikakāminyāṃ lokottarakāminīrūpam parikalpayitum kṣamo vacanaśatenāpi ${ }^{58}$, heyopādeyaparijñānābhāvāt tasya | ata evoktam-

prakāśayișye sattvānāṃ yathāśayaviśeșataḥ|

iti $\mid$

kị̣ tu vācyo guṇạ̣ strīṇām sarvasattvaparigrahạ̣ (!)| kṛpā vā yadi vā rakṣā strīnāṃ citte pratiṣṭhitā ||

āstāṃ tāvat svajanaṃ parajanam api puṣnāti bhikṣayā (!) | sā ced evaṃrūpā nānyathā (!) strī vajrayoginyāḥ || āstāṃ tu darśanaṃ tasyāḥ sprṣțighṛ̣ṭị̣ (!) ca dūratạ̣ | yasyāḥ smarạ̣amātreṇa tatkṣaṇaṃ labhyate sukham || pañcaiva viṣayāḥ strīṇām divyarūpeṇa saṃsthitāh | tām udvāhitāṃ kṛtvā sukhạ̣ bhuñjanti mānavāḥ || [6.72-79]

udvāhitāṃ ${ }^{59}$ vivāhitām |

tasmād bho doṣanirmukte sarvasadguṇamạ̣ḍite | puṇye puṇye mahāpuṇye prasādaṃ kuru me 'mbike || [6.80-81]

puṇya iti punyahetutvāt | ayam arthạ̣ | mahāsukhajñānānubhavaḥ sakalapuṇyakāraṇam, tasya ca kāraṇaṃ prajñaiva | ata evoktam-

\footnotetext{
${ }^{52}$ pāralaukika $^{\circ}$ corr., pāralokika $^{\circ} \mathrm{Ms}$

53 opakārinyo] em., o opakāriṇyāṃ Ms

54 ata] Ms p.c., atah Ms a.c.

55 apunyam] em., apunya Ms

${ }^{56}$ laukika $^{\circ}$ ] corr., lokika ${ }^{\circ} \mathrm{Ms}$

${ }^{57}{ }^{\circ}$ sattvasya, na] em., ${ }^{\circ}$ sattvasyāna Ms

58 ○āpi] em., ${ }^{\circ} \bar{a} m i \mathrm{Ms}$

${ }^{59}$ udvāhitāṃ] em., udvāhitā Ms
} 
yathā latāsamudbhūtam phalam puṣpasamanvitam |

ekakṣaṇātta ${ }^{60}$ sambodhị̣ sambhāradvayasaṃbhṛtā \|

iti $\mid$

tatas tāṃ gāḍhato dṛṣțā svauṣṭhạ̣ dantena pīḍayet |

kurvan śîtkārakạ̣ yogī tāṃ ca kuryād vinagnikām || [6.82-83]

svasyātmana oṣtham svauṣtham ${ }^{61}$ |

kuryāt sukhodaya(!)bandhaṃ bandhaṃ ca dolacālanam | [6.84]

kuryāt sukhodayam ityādy uddeśạ̣|

tatra paryañkamadhye tu striyaṃ cotkuṭakāsanām |

kṛtvā bāhuyugaṃ skandhe svasya gāọhena yojayet || [6.90-91]

tatra paryañketyādi nirdeśạ | etac ca sakalaṃ mṛnmayena ${ }^{62}$ madanamayena vā puttalikādvayena darśayet |

savyena ca kareṇaiva vajrạ̣ padme niveśayet | [6.109]

savyena ca kareṇaivety arthatrayam sūcayati $\mid$ tat prā + lāma +++ ḥ ++ saha $(?)+$ +ḥ ++ | khaḍgamudrāṃ nirnakhāṃ ca (?) + praveśya vāmena ${ }^{63}$ mardayed

vāmāvarttena, [19r] punar dakṣiṇena dakṣiṇāvarttena, yāvat snigdhaṃ bhavati | padmamadhyạ̣ tato jihvāṃ prakṣipya saśabdalehanābhinayena tasyās ${ }^{64}$ tryakṣaram śirasā pratīcchann avalihet katipayakșaṇam | tataḥ savyakareṇa vajrạ̣ gṛhītvā padme praveśayet | evaśabdenaivāyam arthạ̣ pratipādito 'vyayānām anekārthatvād iti | tatreyaṃ khaḍgamudrā — savyahastena muștị̣ dṛ̣̂ham kṛtvā madhyamātarjanyau prasārayed iti |

cumbayec ca mukhạ̣ tasyā yāvadicchaṃ punạ̣ punạ̣ | unnāmya vadanaṃ dṛṣțāa yathecchạ̣ vākyakạ̣ vadan || [6.124-125]

vākyakạ̣ vadann iti kāmottejakạ̣ gosvāminītyādikam (see 6.49) |

jihvāṃ ca cūṣayet tasyāḥ pibel lālāṃ mukhodbhūtām | bhakṣayec carcitaṃ dantamalaṃ saukhyaṃ vibhāvayet \|| pị̣̄ayed dantajihvām īṣad adharapidhānike | [6.126-128]

ịsad ity alpam | yathā vyathā na bhavatīty arthaḥ |

jihvayā nāsikārandhraṃ śodhayen netrakoṇikām ||

${ }^{60}$ ekakșanāātta ${ }^{\circ}$ conj., ekakșanāāt Ms

${ }^{61}$ svaușțham] em., soșțham Ms

62 mṛmayena] corr., mrtmayena Ms

${ }^{63}$ vāmena] conj., vāme Ms

${ }^{64}$ tasyās] em., tasyā Ms 
dantakakṣāṃ ca tajjātạ̣ malạ̣ sarvạ̣ ca bhakṣayet |

mastam netrạ̣ galaṃ karṇaṃ pārśvaṃ kakṣaṃ karaṃ stanam |

cumbayitvā nakhạ̣ dadyāt tyaktvā netradvayạ̣ striyāḥ \||

mardayet pāṇinā cuñcaṃ cūṣayed daṃśayet tatạ̣ | [6.129-133]

daṃśayed iti dantena |

svayam uttānikāṃ kṛtvā cumbayet sundarodaram ||

atraivāhaṃ sthitaḥ pūrvạ̣ smṛtvā smṛtvā muhur muhụ̣ |

hastena sparśayet padmam vāyu sundaram iti bruvan \|

dadyāc cumbanakhạ̣ tatra paśyen niṣkṛ̣ya pāṇinā | [6.134-137]

niṣkṛṣyeti ${ }^{65}$ prakāśya |

ghrātvā gandhạ̣ ca tad randhrạ̣ śodhayed rasanayā striyāḥ \||

pravișțo 'haṃ yathānena niḥsṛtaś cāpy anekaśạ̣ |

vadet tatredṛ́sam vākyaṃ panthāyam nāsikarjụ̣ \|

ayam eva șaḍgateh panthā bhaved ajñānayogatạ̣ |

caṇ̣aroṣaṇasiddhes tu bhavej jñānaprayogatạ̣ || [6.138-142]

ajñānayogato laukikakāmasevāmātratạ | jñānaprayogata ${ }^{66}$ iti

pratipādyamānalokottarakāmasevāyogatạ̣|

tatạ̣ padmagatạ̣ śvetạ̣ raktạ̣ vā sukhasātkṛtaị̣ (!)|

bhakṣayec ca mukhạ̣ tasyāḥ saṃpaśyaṃś ca punạ̣ punạ̣ || [6.143-144]

sotkṛtair iti kị̣citsasuṣiramukhavātākuñcana ${ }^{67}$ śabdaị̣ |

sa nakhạ̣ (!) corukạ̣ kṛtvā mardayed dāsavat padau | mastake tryakṣarạ̣ dadyād dhṛnmadhye laghumuṣtikam \||

tataś citrāt parān bandhān kuryād yogī samāhitạ̣ |

icchayā dhyāyakạ̣ (!) tatra dadyāt saukhyaikamānasạ̣ ||

yathecchaṃ prakṣaren no vā kṣaret saukhyaikamānasaḥ | [6.145-149]

yatheccham ityādi | tatrākṣaraṇopāyas ${ }^{68}$ tu kathyate | yadā maṇimūlaparyantaṃ candro gantum utsahate paramānandānte, tadā mūtravegadhāraṇanyāyena vāyum ākuñcayed dhairya ${ }^{69}$ krameṇa nābhyadhaḥparyantạ̣ śvāsanirodhạ̣ kṛtvā kṣaṇamātram | etac ca guruḥ svayaṃ kṛtvā darśayed iti | etena na kṣaraṇaṃ bhavati |

kṣarite cālihet padmaṃ jānupātaprayogatạ̣ \|

bhakṣayet padmagạ̣ śukraṃ śoṇitaṃ cāpi jihvayā |

nāsayā nalikā(!)yogāt pibet sāmarthyavṛddhaye || [6.150-152]

\footnotetext{
${ }^{65}$ nișkṛșyeti] em., nișkupyeti Ms

$66{ }^{\circ}$ prayogata] em., ${ }^{\circ}$ yogata $\mathrm{Ms}$

$67{ }^{\circ}$ vātākuñcana ${ }^{\circ}$ ] conj., ${ }^{\circ}$ vātāṅkucana ${ }^{\circ} \mathrm{Ms}$

${ }^{68}$ tatrākșaraṇopāyas] em., tatrākșaropāyas Ms

${ }^{69}$ dhairya $^{\circ}$ ] Ms p.c., dhairye Ms a.c.
} 
nāsayetyādi ${ }^{70}$ prayogāntaram āha | ayam arthaḥ | prajñopāyadhātudvayaṃ kadācij

jihvayālihet | kadācit padmān mukhenākṛștam bhājane saṃsthāpya nālikāṃ ${ }^{71}$

prakṣipya śvāsaṃ jñātvā nāsikayābhyavaharet | ghaṇtikārandhreṇety arthạ̣ |

upalakṣaṇam etat, tenāparam api boddhavyam | rajasvalā ${ }^{72}$ raktạ̣

karamudrākṛștaśukram ubhayạ̣ bhājane saṃsthāpyānāmikayā sammardya pūrvavan

nālika $\overline{7}^{73}$ yogenābhyavahared iti | [19v] prayogaphalam āha- sāmarthyetyādi | ayam

arthạ | satata ${ }^{74}$ prayogakaraṇād valipalitavyādhimṛtyunāśanād yogino

mahāsāmarthyavṛddhir bhavatīti |

prakṣālya jihvayā padmaṃ prajñām utthāpya cumbayet |

krọ̣īkṛtya tatạ̣ paścād bhakṣayen matsyamāṃsakam ||

pibed dugdhạ̣ ca madyaṃ vā punạ̣ kāmapravṛddhaye |

śrame jīryati (!) tatpaścād icchayet tu sukhādibhị̣ \||

punạ̣ pūrvakrameṇaiva dvandvam anyonyam ārabhet $\|$

anenābhyāsayogena sādhitạ̣ ca mahāsukham |

caṇḍaroṣapadạ̣ (!) dhatte janmany atraiva yogavit || [6.153-159]

sādhitam iti rātriṃdivaṃ prabandhena sthitam | caṇḍaroṣaṇapadạ̣

mahāmudrāsiddhị̣ dhatte g̣̣hnāti | atraiveti pratyutpanna eva janmani |

rāgiṇāṃ siddhidānārthaṃ mayā yogaḥ prakāśitạ̣ | [6.160]

rāgiṇām ${ }^{75}$ kāminām | ye tv akāminah teșām pāramitānayakrameṇa

trikalpāsaṃkhyeyena bodhir ity ${ }^{76}$ abhiprāyah | vicikitsābahulatvāt teșām nāsmin

dharme śraddhāsti | kāminām api yeșāṃ śraddhā nāsti, na teșāṃ siddhir asti |

etadyogavyatirekaśraddhayāpi nāsti siddhị̣ | na hi ghṛtārthinā jalạ̣ mathanīyam, kị̣

tu dadhir ${ }^{77}$ dugdham vā, tatraiva tasya bhāvād vastuśaktisvābhāvyāc †ce †ti |

bhūmau pādatale sthāpya vakre tiryak sudīrghake |

ardhacandrāsanam jñeyam etat kāmasukhapradam || [6.169-170]

tiryak sudīrghaka iti haṃsapakṣākāre |

punar dhanvāsanaṃ kṛtvā svānanaṃ tadgudāntare |

pātayitvā gudạ̣ tasyāḥ saṃlihen nāsayāpi ca || [6.177-178]

nāsayāpi ceti tatra nāsikāṃ prakșipya gandhạ̣ g̣̣hnīyāt |

tadutpannaṃ sukhaṃ dhyāyāc caṇḍaroṣaṇayogatạ̣ |

tato mukto bhaved yogī sarvasaṃkalpavarjitạ̣ || [6.179-180]

\footnotetext{
${ }^{70}$ nāsayetyādi] em., nāsetyādi Ms

${ }^{71}$ nālikāṃ] em., nālikāyāṃ Ms

${ }^{72}$ rajasvalā $\left.\overline{0}^{\circ}\right]$ corr., rajaḥsvală $\bar{a}^{\circ} \mathrm{Ms}$

${ }^{73}$ nālikā $\left.{ }^{\circ}\right]$ em., nalikā ${ }^{\circ} \mathrm{Ms}$

${ }^{74}$ satata $^{\circ}$ ] em., sa tat Ms

${ }^{75}$ rāgiṇāṃ] em., rāgiṇā Ms

${ }^{76}$ bodhir ity] em., bodhicitty Ms

${ }^{77}$ dadhir] em., dadhi ${ }^{\circ} \mathrm{Ms}$
} 
caṇḍaroṣaṇayogo niścalasamādhih | mukto ${ }^{78}$ duḥkhān muktaḥ, paramasukharūpatvāt

virāgarahitạ̣ cittạ̣ kṛtvā mātrāṃ (!) prakāmayet |

anurāgāt prāpyate puṇyạ̣ virāgād agham āpyate || [6.181-182]

mātām iti yathoktaprajñām | aghạ̣ pāpam |

na virāgāt parạ̣ pāpaṃ na pụ̣yạ̣ sukhataḥ param |

tataś ca kāmaje saukhye cittạ̣ kuryāt samāhitạ̣ || [6.183-184]

atha bhagavatī pramuditahṛdayā bhagavantạ̣ namaskṛtya abhivandya caivam āha $\|[6.185-186]$

bho bhagavan kiṃ nṛ̣āām eva kevalam ayạ̣ sādhanopāyo 'nyeșām api vā || [6.187-188]

bhagavān āha | [6.189]

atrānuraktā ye tu sattvāḥ sarvadikṣu vyavasthitāḥ |

devāsurā narā nāgās te 'pi sidhyanti sādhakāḥ || [6.190-191]

athaivạ̣ śrutvā maheśvarādayo devā gaurīlakṣmīśacīratyādidevatīṃ gṛhītvā bhāvayitum ārabdhāḥ || atha tatkṣaṇaṃ sarve tallavạ̣ tanmuhūrtakạ̣ (!) caṇḍaroṣaṇapadạ̣ prāptā vicaranti mahītale | tatra maheśvaro vajraśan̉ karatvena siddhạ̣ | vāsudevo vajranārāyaṇatvena | devendro vajrapāṇitvena | kāmadevo vajrānañgatvena | evaṃpramukhā gañgānadībālukāsamā devaputrāḥ siddhāḥ || [6.192-196]

tatkṣaṇam ity adhimātrasattvasyānandakṣaṇa eva tattvādhigamāt | tallavam iti madhyasattvasya paramānandakṣaṇa eva tattvādhigamāt $\mid$ tanmuhūrtam $^{79}$ iti mṛdusattvasya paramānande prāpte, viramānandapraveśe, anayor madhye ${ }^{80}$ sahajānandakṣaṇa eva tattvādhigamād iti |

vajraśañkarādīnāṃ tu kathyate rūpam | tatra vajraśañ karo dvibhujaikamukhạ̣ śvetavarṇo jațāmakuṭadharo nirbhūṣaṇapañcamudrāsahito bhasmoddhūlitavigrahas trinetro vāmena kapālakhațvāngadhārī dakṣiṇena ḍamarudhārī sattvaparyañkī vṛṣabhārūọho vajragauryālingitas ${ }^{81}$ taptacāmīkaravarṇayā nānālaṃkāra[20r]bhūṣitayā ṣoḍaśābdayā vāmahastadhṛtaraktapadmayā | vajranārāyaṇo garuḍārūụhaś ${ }^{82}$ caturbhujo nīlo ratnamakuṭ̂̄ sarvālaṃkārabhūṣitaḥ sattvaparyañkī dakṣinenena

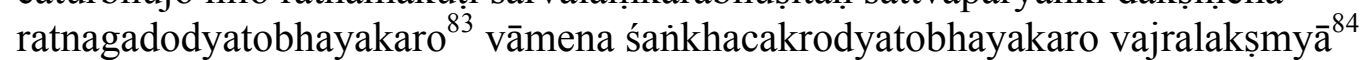
gauravarṇayālingito vajragaurīrūpayā | vajrapāṇir dvibhujạ̣ sahasralocano

\footnotetext{
${ }^{78}$ mukto] em., yukto Ms

${ }^{79}$ tanmuhūrtam] corr., tanmūhūrtam Ms

${ }^{80}$ madhye] em., madhya ${ }^{\circ} \mathrm{Ms}$

$81{ }^{\circ}$ gauryālingitas] Ms p.c., ${ }^{\circ}$ gauryolingitas Ms a.c.

${ }^{82}$ garuḍārūụhaś] em., garuḍhārūụhah | Ms

83 odyatobhayakaro] em., 'odyātābhayakarah | Ms

84 ○lakṣmyā] em., 'lakșmā Ms
} 
ratnamakuṭ̂i sarvālaṃkāradhārī suvarṇavarṇo dakṣiṇena vajradharo vāme tarjanīdhara airāvaṇārūụhah sattvaparyann $\bar{k}^{-15}$ vajragaurīrūpayā vajraśacyālingitah | vajrānañgo makaramukhavimānārūdhah ${ }^{86}$ sattvaparyañkī dvibhujaikamukho ratnamakuṭ̂̄ sarvālañkārabhūṣitaḥ pītavarṇo dakṣiṇe śaradharo vāme kusumacāpadharo vajragaurīrūpayā vajraratyā $\bar{a}^{87}$ lingitạ | tatra maheśvaro 'mitābhaśirasko 'rdhacandradhārī | vāsudevo 'kṣobhyaśiraskaḥ | indro ratnasambhavaśiraskaḥ | kāmadevo 'mitābhaśiraskaḥ | evaṃpramukhā iti vajrakārttikavajragaṇapatyādayaḥ |

pañcakāmaguṇopetāḥ sarvasattvārthakārakāḥ |

nānāmūrtidharāḥ sarve bhūtā māyāvino jināḥ || [6.197-198]

pañcetyādi | pañca kāmā rūparasasparśa ${ }^{88}$ śabdagandhāḥ ${ }^{89} \mid$ kāmyante 'bhilașyanta iti kāmāḥ, ${ }^{90}$ ta eva guṇyante 'bhyasyanta iti guṇāḥ, tair yuktāḥ ${ }^{91} \mid$

yathā pan̉kodbhavaṃ padmaṃ pañkadoṣair na lipyate | tathā rāganayodbhūtā lipyante na ca doṣakaị̣ || [6.199-200]

vastuviśeșasya śaktim āha— yathetyādi | pañkasya kardamasya doṣo varṇagandhādilakșaṇaḥ|

ity ekala(!)vīrākhye śrīcaṇḍamahāroṣaṇatantre niṣpannayogapaṭalaḥ ṣașṭhaḥ || [6.201-202]

niṣpannayogapradhānaḥ ${ }^{92}$ paṭalạ̣ \|

iti șaṣṭhapaṭalavyākhyā || o ||

\footnotetext{
85 oparyañkī] em., ${ }^{\circ}$ paryañkīh | Ms

86 ovimānārūḍhaḥ] em., ${ }^{\circ}$ vināmārūụhah $\mathrm{Ms}$

${ }^{87}$ vajraratya $\left.\bar{a}^{\circ}\right]$ conj., ratyā $\bar{a}^{\circ} \mathrm{Ms}$

88 ० ${ }^{8}$ sparśa $\left.a^{\circ}\right]$ em., ${ }^{\circ}$ sparśāa ${ }^{\circ} \mathrm{Ms}$

$89{ }^{\circ}$ gandhāh] em., ${ }^{\circ}$ gandha Ms

${ }^{90}$ kāmāḥ] em., kāmā Ms

${ }^{91}$ yuktāḥ] em., muktāḥ Ms

92 o pradhānaḥ] em., ${ }^{\circ}$ pradhānam Ms
} 


\section{Translation}

We included George's translation of the müla (1974: 65-78) in bold, printed here as prose, not free verse. We included some modifications, which are discussed in the notes. Minor changes (commas, changes to British English spelling, etc.) are not noted.

Then the Lady, Prajñāpāramitā, firmly embraced the Lord, and having rubbed the Vajra with the Lotus, said: [6.1-2]

[Now we turn to the chapter] beginning with Then. Prajñāpāramitā is Dveșavajrī[, the chief consort of the main deity, Candamahāroșana]. This designation is meaningful (sānvayā). 'Wisdom' (prajñā) [, examined via semantic analysis, ] means a distinguished $\left(p_{r a}{ }^{\circ}=\right.$ prakrștam) gnosis $(j \tilde{n} \bar{a} n a m)$, [that is to say] the gnosis of Innate Bliss (sahajānanda). ${ }^{93}$ 'The other shore' (pāram) means distinguished state, [while] 'gone' (itā) means effortlessly attained, which amounts to 'reached'. Prajñāpāramitā [hence means] 'reached the other shore of wisdom', for it is a cause for the gnosis of Innate Bliss. $\uparrow \ldots \uparrow$ Firmly [is an adverb, i.e.] in such a way that it becomes intensive. ${ }^{94}$

What kind of meditation should be performed by the person practicing the Perfected Stage ${ }^{95}$ ? For the sake of the benefit to yoginīs, please fulfill my request. [6.3-4]

[As for the verse] beginning with The Perfected [Stage] (nispanna[krama] ${ }^{\circ}$ ), the intended meaning is this: to be sure $(h i)$, meditative cultivation [chara]cterised by $\dagger \ldots \dagger^{96}$ is with reference to the Stage of Generation. $\dagger \ldots \uparrow$ should be performed. This is the idea.

\section{Then the Lord said:}

The yogi who is situated in the yoga of the Perfected Stage should be devoted only to yoga. He should meditate day and night on my form with one-pointed mind. [6.5-7]

The perfected stage (nispannakramah) [is the same as what other traditions call] utpannakramah. [As for the passage] with one-pointed mind etc., the meaning is this: the yogī should meditate on himself as having the form of Black Acala or [any] other [ectype of Acala, depending on his affiliation,] with one-pointed mind, [that is to say,] with a mind focused on nothing else, by means of instantaneous visualisation

\footnotetext{
${ }^{93}$ This is from a conjectured reading. We also considered sahajānvayajñannam and the like, but the following passage suggests ${ }^{\circ} \bar{a} n a n d a^{\circ}$ for the problematic part. For the Blisses, see our note to 6.192-196.

${ }^{94}$ Although our conjecture mapped unto some severely effaced aksaras is somewhat tentative, this is perhaps the most likely gloss. Also cf. Mahāsukhavajra ad 6.36 below.

${ }^{95}$ George uses the more customary but slightly inadequate rendering, "Stage of Completion". We have modified this throughout.

${ }^{96} \mathrm{We}$ expect that the lacuna had something with ${ }^{\circ}$ lakșana $\bar{a}$.
} 
(jhatityākārayogena), ${ }^{97}$ not heeding the previously described meditative sequence beginning with [the cultivation of the four brahmaviharas, the first of which is] loving kindness $\left({ }^{\circ}\right.$ maitr $\left.^{\circ}\right) .{ }^{98}$ The implication is that [he should meditate on] his woman as having the form of Dveșavajrī or [any] other [Vajrī, depending on her affiliation]. Day and night is the same as night and day. The meaning is that he should not think of anything else even for a moment.

\section{He should ardently consider his woman ${ }^{99}$ to have your form, until, with great and firm practice, it accordingly becomes perfectly clear. [6.8-9]}

[He should visualise in such a way that it becomes] perfectly clear, [that is to say, in such a way that] the shape $\left({ }^{\circ} \bar{a} k \overline{a r} a^{\circ}\right)$ and identity $\left({ }^{\circ} a h a m k \bar{a} r a^{\circ}\right)$ of those [respective] $\left(\operatorname{tad}^{\circ} . . .{ }^{\circ} \operatorname{tad}^{\circ}\right)$ [deities] become manifest. ${ }^{100}$ And this is achieved by dedicated, uninterrupted, and lengthy repetitions. ${ }^{101}$ As it is said:

Whatever is very intensively meditated on, whether it is real or unreal, will give rise to clear and non-conceptual cognition when the meditation becomes powerful. ${ }^{102}$

\footnotetext{
${ }^{97}$ This is spelt out with a quotation, which we cannot trace in Sanskrit, in the commentary to the last chapter (Ms 33r): büjenāpi vineti jhatityākārayogena $\mid$ tathā coktam-yadvā jhațitiyogena vajraḍakkah svayam bhavet | bhāvayitvā vinā bïjam upapādukasattvavat \|; "Even without the seed[-syllable] [i.e.] by means of instantaneous visualisation. As it is taught: Alternatively, he should become Vajraḍāka by means of instantaneous visualisation, after having meditated [on it] without the seed[-syllable], like the being which is spontaneously born."

${ }^{98}$ See 4.7-8 ff. in George's numeration. The point is that the Mahāyāna prelude and other gradual practices of the Stage of Generation (utpattikramah) are not to be performed at this level.

${ }^{99}$ We modified George's translation "his own wife", since it was probably not a requirement to formally marry the consort.

${ }^{100}$ George here (1974: 66, n. 59) makes reference to the commentary; while he managed to capture the overall gist of the passage, it is based on a misreading of the manuscript (sphutatām iti tadahamkarayoḥ).

${ }^{101}$ These three attributes of meditative cultivation are commonplace in non-tantric Buddhists texts and tantric authors adopt it almost automatically. On a tantric level, however, 'lengthy' is somewhat relative; for one of the key strengths of deity-yoga is that achievement is reached quickly. We do indeed find the third item dropped, e.g. Pañcarakșāvidhāna, Sädhanamālā 206 (Bhattacharya 1928: 406), and even replaced with ${ }^{\circ}$ dṛ̣hāveśah, 'a firm intentness', e.g. TārodbhavaKurukullāsādhana, Sädhanamāla 172 (Bhattacharya 1928: 349). Note the usage of āveśah, which is primarily used for possesion by deities and demons.

${ }^{102}$ This is Pramānavārttika, Pratyakșapariccheda v. 285 (= Pramānaviniścaya 1.31) slightly rewritten and somewhat garbled in transmission. The verse is quoted very often and with fluctuating readings, cf. Isaacson \& Sferra 2014: 169, 267 (we follow this translation with a slight modification to $p \bar{a} d a$ a) and Kuranishi 2016: 54. We can add two more instances to the already rather exhaustive survey of Buddhist and Śaiva testimonia in the two cited works: (Pseudo-)Padmavajra's Advayavivaranaprajñopāyaviniścayasiddhi (Samdhong Rinpoche \& Dwivedi 1988: 218, which transmits ${ }^{\circ} b a l a^{\circ}$ in $p \bar{a} d a c$, and the even pādas in a corrupt form: yad yad eveti bhāvyate and tasya sākalyadhīh phalam); and Sucaritamiśra's Kāśikā
} 
[And: $]^{103}$

Through the power of repetition, both real and unreal things appear manifest for men, just like beautiful women for those tormented by lust. Verily, the practice of yoga (yogayuktih) depends on the mind (cittānuyātā). ${ }^{104}$

Mother, daughter, sister, niece, and any other female relative, ${ }^{105}$ as well as a
Dombini, ${ }^{106}$ [the] female [relative of a] Brahmin, ${ }^{107}[6.10-11]$

(Sāmbaśiva Śāstrī 1926: 215, which too has ${ }^{\circ} \bar{a} t i b h a \bar{v} v y a t e$ and ${ }^{\circ}$ bala ${ }^{\circ}$, but ${ }^{\circ}$ dhīh phalam in the last $p \bar{a} d a$ ). Mahāsukhavajra seems to have recomposed $p \bar{a} d a a$, which is invariably transmitted as tasmād bhütam abhütam vāa. This is understandable, since tasmād, 'therefore' would not have made much sense here. In the next two verse quarters, we find atibhāvyate vs. abhibhāvyate and ${ }^{\circ}$ balanispattau vs. ${ }^{\circ}$ parinișpattau almost equally distributed in the testimonia. As for $p \bar{a} d a d$, it is evident that at some point in the transmission of Mahāsukhavajra's text, tat and $s p h u t \bar{a}^{\circ}$ exchanged places. We cannot see any good explanation for this, unless either of these two words became at some point a marginal correction and was subsequently reinserted into the main body in the wrong place. There does not seem to be any legitimacy for the visarga in ${ }^{\circ} d h \bar{t} h$, but this is somewhat disturbingly not the only time we see this form, cf. for instance the readings of Pseudo-Padmavajra and Sucaritamiśra just above, but also Ratnakīrti's Sarvajñasiddhi (Thakur 1957: 9, which also erroneously prints sphuțā $k$ alpa $^{\circ}$ ), Vāgīśvarakīrti's Tattvaratnāvalokavivaraṇa (Pandey 1997: 144), as well as the best manuscript of Ratnarakșita's Padminī (Ms, 22r), granted, ante correctionem, and therefore justifiably not mentioned in the critical notes in Kuranishi 2016. The main point is that an intensively cultivated concept or image qualifies as direct perception (pratyaksam) of the yogic kind $\left(y o g i^{\circ}\right)$, inasmuch as it is "clear" (which essentially means the same as abhräntam, 'non-erroneous' in the standard definition of direct perception) and "non-conceptual" (kalpanapodham in the standard definition).

${ }^{103}$ Perhaps something like *aparam ca is missing here, otherwise Mahāsukhavajra might create the impression that the two verses are from the same source.

${ }^{104}$ This is from the Vāksādhana of Sujanabhadra, Sādhanamālā 66 (Bhattacharya 1925: 135, where for some reason $p \bar{a} d a d$ is printed as a long compound).

Alternatively, one may understand 'yuktih as 'logic', 'the way [yoga] works'.

${ }^{105}$ Judging by his final sentence to this passage, we think that Mahāsukhavajra might have taken jñātinīm in a weaker sense, such as 'intimate friend'.

${ }^{106}$ George has "female musician", but this was not the only occupation associated with this group well outside the caste system. He probably opted for this meaning, because he wanted rajaki in the next line to be a washerwoman. However, these were, as their name shows, dyers, although it is of course true that the two occupations are related and probably also performed by the same people. We leave it to ethnographers to establish whether dombas are related to the Dom people. Elsewhere (Ms 15r), Mahāsukhavajra suggests that the primary feature of dombinīs was their black skin colour (krṣnakanyām iti dombinīm), and that there was considerable racism directed towards them (ibid.): krșnakanyādīnām lokaviruddhatvāt; "[And the yogī should make love to them in such a way that nobody finds out,] for black girls etc. are considered forbidden by society." 
[We now turn to the verse] beginning with Mother. [The yogin] should take a consort ( ${ }^{\circ}$ prajñ̄am) beginning with 'mother', but only one in which youth has not yet faded. ${ }^{108}$ As everyone knows (kila), men will become exceedingly engaged with whatever object their mind is set upon. [Now,] although their mind is engaged, they will turn it away [from that object, in this case women,] because of fear from society $\left(l o k a^{\circ}\right)$. But [then] they will experience intense suffering caused by [this] turning away. Because of [this] suffering, there will be a distraction (viksepah) of mind, and because of that [distraction] there will be a lack of composure (samādhāna ${ }^{\circ}$. And if there is a lack of composure, there will be no achievement of the Great Seal (mahāmudra $\bar{a}^{\circ}$ ) (i.e the ultimate state).

Moreover, it should not be supposed that [engaging with women in such a way] contradicts religion (adharmah), because there is no injury either to oneself or to others. Nor is there $\uparrow \ldots \uparrow$, because of its having the form of experiencing Great Pleasure ${ }^{109}$. On the contrary, this is producing [spiritual] profit both to oneself and to others. ${ }^{110}$ To explain:

Correctly producing [spiritual] profit to oneself and to others, one will gain merit. In the contrary case, [one will accrue] sin. The [karmic] fruit[s], pleasure and suffering, are [the result] of these two [respectively]. ${ }^{111}$

Nor is there sin from the type of consort [chosen], because that would contradict [what] other tantras [teach]. As said, amongst others:

The mother, the sister, the sister's daughter, ${ }^{112}$

As for [the scriptural and exegetical passages,] where [it is stated that] the words 'mother' etc. denote the eyes etc., those [seek to] hide reality from beings unworthy [for the practice of the esoteric path] $\left(a b h a v y a^{\circ}\right)$. Were it otherwise, [namely] that some people removed the words 'eyes' etc. and replaced it with antisocial (lokaviruddha ${ }^{\circ}$ ) words like 'mother' etc., then it would simply be the case that these are the ravings of madmen. ${ }^{113}$

${ }^{107}$ George has "Brāhman", which sounds male. At any rate, strictly speaking women do not possess caste, because that status is inherited from the father's side.

${ }^{108}$ This point, that the consort should be young, is emphasised in several places in the commentary, e.g. Ms 14v, 15r.

${ }^{109}$ Achieving Great Pleasure is the same as achieving buddhahood, cf.

Mahāsukhavajra (Ms 30v): buddhasiddhim mahāsukhasiddhim.

${ }^{110}$ This contrast, adharma being injury (apakarah) to both oneself and others and its opposite, i.e. dharma, being benefit (arthakaranam = upakārah) to both oneself and others, might allude to standard definitions of these two terms.

${ }^{111}$ We were unable to trace this verse.

${ }^{112}$ Most likely Hevajratantra II.vii.11 ab (Snellgrove 1959: 88). Also cf. Mahāmudrātilaka 23.28 (Ms 49r), Vajrad̄ākatantra 1.48 (Sugiki 2002: 91), Abhidhānottara 48/51.18 (Chandra 1981: 246).

${ }^{113}$ What Mahāsukhavajra has in mind here is most likely a passage in Kṛṣnācārya's commentary of the Hevajratantra, the Yogaratnamāla, where the Buddhakapālatantra is quoted (Snellgrove 1959: 155-156; Tripathi \& Negi 2006: 
Among these [mentioned consorts], mother can mean birth mother, stepmother ${ }^{114}$, maternal aunt, or the wife of the master ${ }^{115}$. Daughter can mean fathered daughter ${ }^{116}$, brother's daughter, the daughter from a previous marriage of a woman brought into wedlock together with her ${ }^{117}$, or the daughter of the master. Sister can mean one related by blood ${ }^{118}$, the daughter of a maternal aunt, or the daughter of the master ${ }^{119}$. Niece means the daughter of any of these [previously listed]. Any other means those

180-181; Farrow \& Menon 1992: 270; for the Buddhakapāla quotation, see Luo 2010: 29, 102). We give here the text slightly standardised and with our own translation, since that of Farrow \& Menon is inadequate. [...] mātrādiśabdaih pañcendriyāny abhidhīyante, tāni śabdarūparasādibhih pañca kāmaguṇais tarpayet | iyam eva hi tatra sthānam devīnām niruttarā pūjeti | katham mātrādayaś cakṣurādaya iti cet $\mid$ tathā coktạn Buddhakapāle yoginìtantre-[...] bhagin̄̄ bhavec cakșur bhāgineȳ śrotram eva ca || jananī bhanyate ghrānam rasanā duhitā tathā $\mid$ mano bhaved bhāryā | șa et etā varā divyā mahāmudrāpradāyikāh || iti |; "The words beginning with 'Mother' denote the five sense faculties. Those should be propitiated with the five objects of desire, viz. sound, sight, taste, etc. For there (i.e. in the ganacakra) it is this, which is the suitable unsurpassed worship of the goddesses. Now, if one were to ask: 'How is it that [the words] mother, etc. [denote] the eyes, etc.?' As it is taught in the yoginitantra [called] the Buddhakapāla: The sister is the eye, the niece is the ear, the birth mother is the nose, the daughter is the tongue, the mind [here: the sense faculty of the body, i.e. of touch] is the wife." While Mahāsukhavajra strongly disapproves of this interpretation, he seeks to defend the authority of both scripture and co-exegete by claiming that they are shielding the truth from those unprepared.

${ }^{114}$ We do not find the compound sapatnamātā elsewhere, the interpretation is therefore conjectural. Cf., however, our note to 6.38 .

${ }^{115}$ This is highly unusual, since the guru's consort is off limits. Cf.

Cittaviśuddhiprakarana 129ab (Patel 1949: 9): guror ājñām ca mudrām ca chāyām api na langhayet |; "He should not transgress his guru's command, mount his consort, or even step over his shadow." This is our interpretation, as we are not convinced that Varghese (2008: 260) understood the line: "One should not transgress the commands of one's preceptor, nor one should not (sic!) forget his $m u d r a \bar{s}$, or even his shadow." Also cf. Prajñopāyaviniścayasiddhi 2.14cd-15ab (Samdhong Rinpoche \& Dwivedi 1988: 71): vihețhayanti cātmānam ātmanaiva durāśayāh | harane gurumudrāyā ratnatrayadhanasya ca |; "Wicked men bring misfortune upon themselves if they steal the guru's consort or the wealth that belongs to Three Jewels." Note that we read this with the variant ${ }^{\circ}$ dhanasya, and not ${ }^{\circ}$ dharasya as in the constituted text. Also cf. the Dākinijjālaśamvararahasya (Samdhong Rinpoche \& Dwivedi 1990: 11), a quotation from the [Dākin̄i] vajrapañjara: guroś chāyām na langhayed [guru]patnīm ca pādukā [m] | ye langhayanti sammohāt te narāḥ kṣuradhārinah ||; "He should not step over the guru's shadow, mount the guru's wife, or use his sandals. Those men who do [so] out of delusion, will go to the Razor-edged [hell]."

${ }^{116}$ Again, we do not find this meaning in the standard dictionaries, but it is the most logical choice.

${ }^{117}$ This is stated in a very roundabout way, and our interpretation is somewhat tentative.

${ }_{118}$ Presumably sharing at least one parent.

${ }^{119}$ In this case presumably one of more or less the same age with the yogi. 
[different] from the four [just mentioned], who are defined below.

\section{Caṇḍālī, ${ }^{120}$ dancer, dyer, ${ }^{121}$ and prostitute; holy woman, ${ }^{122}$ yogin̄̄, and kāpālinīi ${ }^{123}$ as well- ${ }^{124}[6.12-13]$}

Prostitute $^{125}$ (lit. 'she who makes a living of her body/beauty') means a harlot who will not charge a fee [for taking part in the ritual] (agrhìtapanyām).

\section{Or else, whatever he may find fashioned into a woman's figure: ${ }^{126}$ these he should serve ${ }^{127}$ in the proper way without disclosure. ${ }^{128}[6.14-15]$}

What will happen if there is a disclosure [of one's participation in these practices]?

${ }^{120}$ George translates this as "sweeper", but once again we are dealing with an obscure marginal group with various occupations. Candālas are the par excellence untouchables. On how to gain such a woman, see the famous passage from Padmavajra's Guhyasiddhi discussed in Sanderson 2009: 144-145.

${ }^{121}$ George's "washerwoman" has already been discussed above.

122 This, George's translation, is perhaps a bit too strong, but we left it as it is for lack of a better rendering. We think that it can be any woman undertaking a religious observance, e.g. a nun.

${ }^{123}$ This time George's "ascetic" is too narrow. The word means a female kāpālika, i.e. probably a Śaiva.

${ }^{124}$ In addition to these, later on we have widows, etc. Mahāsukhavajra, perhaps not

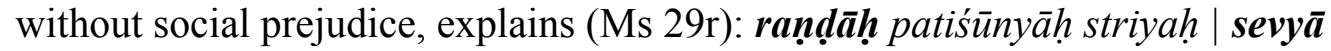
vajrapadmayogena $\mid$ yatinyo bhikṣuñtapasvinyādayah $\mid$ prāyena kila ranḍāīnām (em., randạdīnam Ms) idam eva satatam cetasi garjati: katham purușasamparko bhavatv iti | lokabhayāe ca purușā na pravartante| śaktasya tu yogino na lokabhayam asti | atas tena sevanīyāh |; "Widows means those women, whose husbands are absent. Should be served means by uniting the Vajra with the Lotus. Female ascetics means [Buddhist] nuns, anchoresses, etc. As everyone knows, generally widows etc. constantly obsess over how they could make contact with men. But men do no act on this, because they fear society. However, a powerful yogī does not fear society, therefore he should serve them." A 'powerful yogì' is an experienced one. Elsewhere (Ms 21r), 'power' (śaktih) is glossed as the magical capability to paralise or kill. When the yogi is perceived to have gained these powers, he will not be vexed by society or royal authority, because they will fear him.

${ }^{125}$ Note George's slightly different and metrically correct reading, rūpajīvikām.

${ }^{126}$ We modified George's slightly ambiguous "Or whatever other he may receive with a woman's figure." This line is explained by Mahāsukhavajra just below.

${ }^{127}$ Of course, the root sev has a strongly sexual connotation, as Mahāsukhavajra himself makes this clear elsewhere (Ms 29r), see three notes above.

${ }^{128}$ The point here is that the practice should be performed observing strict secrecy (cf. 6.19-20). If it is divulged, great calamity will befall the yogī (cf. 6.16-18). We could not therefore agree with George's interpretation of bhedah here and in the next verse as "making any/makes a distinction". The $p \bar{a} d a$ yathā bhedo na jāyate is an echo of Hevajratantra I.v.3 (Snellgrove 1959: 16), where the opposite situation is introduced by agupte, "[but] if it is not hidden". We find the same collocation yathä bhedo na jāyate in two early sources: Padmavajra's Guhyasiddhi 6.94b (Samdhong Rinpoche \& Dwivedi 1988: 47) and the Advayasamatâvijaya (Fan 2011: 164). 
[The Lord] explains [this in the next verse,] beginning with But if there is a disclosure.

But if there is a disclosure, Caṇdamahāroṣaṇa will be angered ${ }^{129}$ and slay the practitioner. And he will throw him into the Avici Hell threatening ${ }^{130}$ him with a sword and noose. ${ }^{131}$ Nor will he obtain Success in this world or the next. Therefore, this must be kept very secret and not be made visible. Like the mantra of the Ḍākin̄i, ${ }^{132}$ the practice of Caṇ̣amahāroṣaṇa should be secret. [6.16-20]

Objection (nanu)! If this is so, then what is the point of teaching all this, which causes great misfortune? [This is] explained [with the next verse] beginning with Exceedingly $\left(\operatorname{atyanta}^{\circ}\right) .{ }^{133}$

\section{And this has been explained by me, the Buddha, for the sake of those who are exceedingly passionate. [6.21]}

The meaning is this: this [i.e. the body of practices advocated by this scripture belong to] the vehicle of passion (räganayo) ${ }^{134}$ And once passion has arisen, it should never be avoided.

Or, if this [proves] impossible [to perform as prescribed, that is to say, if one cannot find a] flesh and blood [woman] (sākșann), ${ }^{135}$ then one should rely on a likeness of the [consort] (tatpratikrtim), made of [a suitable substance] such as wood $\left(\right.$ darru $\left.^{\circ}\right),{ }^{136}$ or painted on a cloth $\left(p a t a^{\circ}\right)$.

${ }^{129}$ Perhaps more suitable than George's "provoked".

${ }^{130}$ George has "and threaten him"; we modified this to a more correct rendering of the present participle.

${ }^{131}$ Perhaps more correctly "his sword and noose", since these are the two implements of the deity.

${ }^{132}$ We are puzzled by this expression: which $d \bar{a} k i n \bar{\imath}$ does the author of the mūla have in mind and why should her mantra be more secret than other spells?

${ }^{133}$ Here too we must disagree with George. His chosen reading is (in spite of two of his manuscripts suggesting otherwise) abhyantakāminām, which he translates as "those who cherish the esoteric".

${ }^{134}$ Mahāsukhavajra presumably borrows this expression from the last verse of the present chapter. The more common expression is mahäräganaya, 'the vehicle of great (or special) passion', i.e. one in which common rāga is transmuted towards spiritual means, as alluded to immediately below, ad 6.160.

${ }^{135}$ This explanation looks back at 6.14.

${ }^{136}$ Consorts fashioned out of wood etc. are also mentioned in Śrībhānu's commentary of the Vajrämrta, a passage recycled in scripture, the Samputodbhava (Szántó 2016: 414). For a cultural history of (Western) sex dolls, see Ferguson 2010. Although the theme itself is not unknown in Classical literature, this work claims that the most direct antecedent can be found in cloth fornicatory dolls used by sailors on long voyages in the 17th c. (2010: $16 \mathrm{ff}$.). The study completely ignores pre-contemporary non-Western material, except stating that the Japanese adopted the concept from Dutch seamen and sometimes refer to these objects as datch [i] waifu, 'Dutch wife' (2010: 27). 
And this should be performed only in an isolated place, [therefore the next verse] begins with [Pleas]ing to the mind. ${ }^{137}$

In a place pleasing to the mind ${ }^{138}$ where there are no disturbances, in secret, after having taken ${ }^{139}$ a lover who is agreeable to his mind, ${ }^{140}[6.22-23]$

In secret means covered [from prying eyes by means of] a wall $\left(b h i t t i^{\circ}\right)$, a screen $\left({ }^{\circ}\right.$ pațala $\left.{ }^{\circ}\right)$, a door-panel $\left({ }^{\circ}\right.$ kapa $\left._{t} a^{\circ}\right)$, or [something similar]. Having taken means having grasped. A lover who is agreeable to one's mind means any [woman] from among [those listed before,] whom his mind finds attractive.

"I am Buddha and the Perfected One, ${ }^{141}$ Immoveable, ${ }^{142}$ she is cherished Prajñāpāramitā," thus the wise person should meditate with fixed thought, each one having their ${ }^{143}$ respective [divine] form. [6.24-25]

The [compound] each one having their respective [divine] form clarifies what has been stated already. The meaning is this: [the yogī] should not meditate observing the practice [of visualising] the deity as in the Stage of Generation, [that is to say visualising] the colour, the shape, the arms [with hands holding implements] such as the sword [and] the chopping knife ${ }^{144}$, the legs, [and performing the] installation [of mantras on the body], and so on. Instead, he should [instantly] perform visualisation [of himself and the consort in] whichever colour, shape, etc. is naturally suited to him and his [consort]. ${ }^{145}$

${ }^{137}$ The lemma is somewhat unusual. George's edition does not compound the first two words, which is probably a misprint.

${ }^{138}$ Although George's translation, "In a pleasing place" is perfectly fine, we changed it slightly to allign it with how we translate the lemma of the commentator.

${ }^{139}$ We translate the absolutive more literally than George's "he should take".

${ }^{140}$ Again we translated more literally than George, who has "a woman who has desire".

${ }^{141}$ Or perhaps 'a perfected one', a siddha.

${ }^{142}$ That is to say, Acala, the main deity otherwise called Candamahāroșana.

${ }^{143}$ Rather than simply "his" as George has it, since both the yogi and the consort assume divine forms.

${ }^{144}$ This is the chief implement of the goddess.

${ }^{145}$ This, somewhat free translation is the result of a relatively confident conjecture (prakrtisiddham, tenaiva for prakrti +++ naiva). The passage alludes to $4.78-89$ (tr. George 1974: 62-63), a teaching seemingly advocating that the deity-affiliation of practitioners can be established by their skin tone. Thus, those of dark complexion should cultivate themselves as black Acala, those fairer as white Acala, etc. To this, Mahāsukhavajra adds (Ms 14v-15r): prakṛtisiddhā eva narā nāryaś ca, kim tv anādyavidyāvāsanopahatāḥ | tadavidyāvāsanānāśanārtham tu devadevībhāvanā kriyate | bhāvanā ca prakrtisiddhavarnena śighram eva sphutatarā bhavati | tatsphutībhāvād dhi mahāmudrāsiddhih | "Both men and women are by their very nature accomplished, but they are afflicted by the imprints of beginningless ignorance. It is precisely in order to destroy these imprints of ignorance that the cultivation [of oneself] as gods and goddesses is performed. And [this] cultivation becomes exceedingly clear very quickly if [performed] according to one's natural 
And having made a lonely hermitage, and with food and clothing as obtained, they should meditate ardently by the practice of copulating with each other. ${ }^{146}$ [6.26-27]

[Now for the compound] beginning with As. [The compound yathālabdhānnavastrakah ${ }^{147}$ is a bahuvrīhi meaning] he who [finds] pleasure (kam), [that is to say] comfort (sukham), with the nourishment and the clothing as [he had] obtained [them]. In other words, he should not entertain [dichotomies such as] 'this food etc. is agreeable', 'this [food etc.] is not [agreeable]'. Practice of copulation means the practice of embracing and so on.

He should bring the woman into his presence and seat her before him. Each should gaze steadily at the other, with mutual desire. Then, concentrating on the visual pleasure $^{148}$, he $^{149}$ should remain with one-pointed mind. Just then she should utter the following speech, which arouses pleasure. [6.28-31]

[We will now explain the meaning of] visual pleasure. As everyone knows (kila), beholding the limbs and body parts ${ }^{150}$ of women produces great pleasure indeed. The meaning is that therefore he should remain (i.e. pause) for a few minutes contemplating that pleasure, after having become motionless like a log (kāșthavan), together with whichever consort who [is able through her beauty to give] rise to that [visual] bliss. He should then contemplate auditory pleasure [in a similar way]. [This is explained in the line] beginning with She. [Speech,] which arouses pleasure means [speech] which intensifies the previously arisen pleasure (i.e. the one obtained through sight).

"You are my son and my husband; you are my brother and father. I am your mother, wife, sister, and niece. Together with seven generations of your paternal

complexion. And when this becomes clear, one achieves the Great Seal." Elsewhere (Ms 10r), it is suggested that the initiate has the option to either choose an ectype of Acala at will or to chose the one suited to his skin colour (sväbhilāsatah, svedehavarnato $v \bar{a}$ ). Normally this affinity is established by throwing a flower or a small garland on the mandala or a copy thereof.

${ }^{146}$ George has "he should meditate ardently-the two coupled with each other." However, we interpret dvābhyām ... bhāvayen as an ergative construction (also see 6.29 , dvābhyām ... İkșayet), which might point to the fact that the author was thinking in Newar occasionally.

${ }^{147}$ Mahāsukhavajra's reading must have been this, and not George's ${ }^{\circ}$ vastukaḥ, we therefore changed his translation mirroring that reading, "with whatever he has for food and property". We suspect that the original author of the tantra did not think much of including the kan suffix as a verse filler, but this is an opportunity for the commentator to display some sophistication.

${ }^{148}$ We translate more literally here; George has "enjoyable view".

${ }^{149}$ George has "each", which might fit the context semantically, but it does not follow the grammar.

${ }^{150}$ The limbs (angam/angāni) are the head, the trunk, the arms, and the legs. What we here translate as 'body parts' for lack of a better English word

(pratyaingam/pratyaingāni) include the forehead, the nose, the chin, the fingers, etc. 
ancestors, you are my slave, ${ }^{151}$ my phlegm-eating ${ }^{152}$ lowly servant. I bought you with cowrie shells ${ }^{153}$; I am called ${ }^{154}$ your mistress." [6.32-35]

The two verses beginning with You are my son should be recited by the woman with a shrill ${ }^{155}$ intonation in the $\uparrow \ldots \dagger^{156}$ scale while beholding the man. Then, after having contemplated for a few minutes the pleasure arising from that (i.e. her voice and words) in line with the process described previously, he should worship her.

He should fall at her feet ardently with his palms pressed together. Then he should utter this speech arousing the highest pleasure. [6.36-37]

[This is explained] beginning with And he should fall [at her feet ${ }^{157}$. Ardently means in a way that it becomes so (i.e. adverbial usage).

"You are my mother, ${ }^{158}$ my father's wife, and you are my niece. You are my sister, my son's wife, you are my paternal aunt and maternal aunt. ${ }^{159} \mathrm{I}$ am your slave in all ways, keenly active in devotion to you. $O$ Mother, look upon me with kindness, casting a loving glance." [6.38-41]

The two verses beginning with You are my mother should be recited by the yogi in the manner stated before. In case [either or both] lack a melodious voice $\left(\operatorname{svara}^{\circ}\right)$, then the recitation should be performed with grace (lälityena). The words brother,

${ }^{151}$ This is a tentative translation, but perhaps more plausible than George's "For seven generations you have been my slave".

${ }^{152}$ George discreetly avoids translating khețasa ${ }^{\circ}$. Ms Gt reads khețāsa ${ }^{\circ}$, which we correct to khețāśa ${ }^{\circ}$.

${ }^{153}$ Or perhaps: 'a single cowrie shell'. Cowries (kapardakah) were used as coins of minute denomination (Gopal 1989: 213-214). In other words, he is being told that he is a cheap slave.

${ }^{154}$ Or perhaps: 'I am to be addressed as "mistress" by you'.

${ }^{155}$ We translate thus with some hesitation. The Pạninīyaśikṣā 34c (Ghosh 1938: 72) lists kākasvaram (which Ghosh translates as 'repressed tone') as a fault in recitation. Perhaps the text means the voice of a crow, but the crow is considered unpleasant and inauspicious, so it is difficult to see how such an intonation could be construed as erotic. We have also considered emending to $k \bar{a} k u^{\circ}$, in which case the verse would be recited in a slightly ironic, sarcastic, and therefore jestful (even 'kinky') tone. This would be more suited to the second verse, in which she describes the man as her slave, etc.

${ }^{156}$ We are unaware of any musical scale called kahu or anything even remotely similar.

${ }^{157}$ The presence of the enclitic ca in the lemma is somewhat surprising. Perhaps Mahāsukhavajra read a different version, e.g. *patec ca pādayos tasyā. We included the enclitic in the translation.

${ }^{158}$ We disagree with George's compounding mātā and pitur and therefore with his interpretation "You are my mother's father's wife"; cf. Mahāsukhavajra's list of what 'mother' means ad 6.10 above.

${ }^{159}$ George compounds bhaginīputrabhāryā and translates as "my mother's father's wife". His interpretation of svasā (correctly: șvasā) as 'sister' is puzzling. Māmikāa a Sanskritised vernacular word, is not simply aunt, but maternal aunt. 
mother, etc. are taught with the aim of intensifying [the couple's] pleasure.

Then she, after having embraced the man, ${ }^{160}$ should kiss him again and again. She places the Three Syllables on his head, and in his mouth, the juice of the mouth, honey ${ }^{161} \cdot[6.42-43]$

The Three Syllables [should be] accompanied with the gesture of a hollow fist. ${ }^{162}$ The juice of the mouth means a globule of phlegm, expectorated loudly. The same is [said to be] like honey, for it gives rise to the pleasure [experienced when consuming] honey.

She should have him suck the Lotus, and show him rolling eyes. Placing lipstick on his mouth, she should press his heart ${ }^{163}$ with her breast. [6.44-45]

The Lotus means the vulva. She should have him suck means that the yogini should draw the head of the yogi to her lotus grabbing him by the hand ${ }^{164}$. Until the completion of cunnilingus ( $\bar{u}$ șanakriy $\left.\bar{a}^{\circ}\right)$, the yoginī should from time to time rest [her hand] on the yogī's head and bestow the three syllables. ${ }^{165}$ Then, once that has been completed, the yoginī should lift the yogī's head and should roll her eyes, ${ }^{166}$ [that is to say,] she should look at him with sidelong glances (kațāssam). ${ }^{167}$

In front of him, looking him in the face, ${ }^{168}$ she should scratch him wherever

${ }^{160}$ We favour the reading ślișțā over ślișțā; George's translation, “in the man's embrace", is modified accordingly.

${ }^{161}$ We translate more literally than George, who has "sweet saliva", also taking madhu as a noun, as does Mahāsukhavajra.

${ }^{162}$ This is the result of a conjecture. Without the $s a^{\circ}$ the text would be saying that the Three Syllables are a gesture, which seems absurd to us. The Three Syllables or the Triad of Syllables (tryakșaram) is usually om āh hüṃ, cf. om āh hụ̣̈ iti tryakṣaram in the Mañjuśrīsādhana, Sādhanamālā 51 (Bhattacharya 1925: 107); om āh hūm iti tryakșarena in the Kurukullāsādhana of Kṛ̣ṇa, Sādhanamālā 181 (Bhattacharya 1928: 376); om ạh hūm sitanīlapittatryakșarāni cintayet in the Pratisarāsādhana, Sädhanamālā 194 (Bhattacharya 1928: 396). George was seemingly puzzled by this reading, too (1974: 68, n. 60): "As explained in the Comm., this is a light blow on the top of his head with a partially closed fist. Why "Three Syllables" is not explained." Also see our note to 6.146 below. The corruption can be easily explained as a kind of haplography, since $s a$ and $m a$ look very similar.

${ }^{163}$ A very minor point: observing correct sandhi, this should be pịdayed dhṛdam. We also suspect that this reading might be a corruption of pīdayed dṛ̣ham.

${ }^{164} \mathrm{We}$ feel a little hesitant here, because the expression usually means extricating one's hand.

${ }^{165}$ The idea seems to be that she rests her hollow fist on his head from time to time, while reciting om ă h̆ hüm.

${ }^{166}$ Another minor point: Mahāsukhavajra's lemma is missing the vi ${ }^{\circ}$.

${ }^{167}$ This, as any reader of Indian poetry and ars amatoria will surely know, is considered a most erotic eye gesture.

${ }^{168}$ It is somewhat doubtful that this is what Mahāsukhavajra read. 
Then the yoginī should make the yogī lay down, facing upwards. Then she should place ${ }^{170}$ her anal lotus and her vaginal lotus in front of his mouth, recite the three syllables, and say Eat Vairocana! and so forth. [Then] she should quickly give [those substances to him] as she pleases. ${ }^{171}$ Vairocana means faeces.

Drink the Aksobhya-water ${ }^{172}$, O Son! Be a slave along with your father! ${ }^{173}$ I am your cow-girl ${ }^{174}$ as well as your royal mother. [6.48-49]

Aksobhya-water means urine. As for the yogī, he should take all that with reverence $^{175}$, become still [for a few minutes], and contemplate nothing but the pleasure [derived from ingestion]. Then she should make him rise once again and address [him the words] beginning with ${ }^{176}$ [Be a slave] along with your father.

Constantly take refuge at my feet, my dear. You were raised by me, hence your invaluable nature. $[6.50-51]$

[Now for the passage] beginning with By me. [You] have been brought up by me, assuming the shape of [your] mother, in your childhood with breast milk etc. [Hence your] invaluable, [that is to say,] priceless [nature, i.e. present state]. The implied meaning is [that by this fostering the yogī has assumed] a distinguished state.

${ }^{169}$ We favour Mical's more metrical reading nakham dattvocitālaye over George's nakham dattvā cittālaye. His translation, "she should pinch him on the chest", has been modified accordingly. The appropriate places for scratching (breasts, cheeks, etc.) are listed in erotic guidebooks, e.g. Nägarasarvasva, chapter 22 (Shukla Shastri 1994: 85-87), but also in this chapter, see 6.131-132 below.

${ }^{170}$ The absolutive arpya is a slight blemish (lyap for $\left.k t v \bar{a}\right)$. One could of course emend it to samarpya, but it is not out of the question that this reading is original and was inspired by the mūla, cf. 4.103-104.

${ }^{171}$ We feel somewhat hesitant about the conjecture yathārucy āśu for yathārūvyā, but *yathārucyā is not attested for the indeclinable adverb yathāruci. However, it is not out of the question that this was indeed the reading, an idiosyncratic usage on the author's part.

${ }^{172}$ Understand akṣobhyajalam as a karmadhāraya compound ("the water which is Akșobhya") and not as George, a genitive tatpurușa ("water of Akșobhya").

${ }^{173}$ The instrumental pitrā would have sufficed, $\mathbf{s a}^{\circ}$ is therefore probably a verse filler. Alternatively, emend to sapitā. We hope this addresses George's worries expressed in 1974: 68, n. 63 and improves his translation, "O Son, be a slave as well as a father!"

${ }^{174}$ George translates this as "formal wife", but it is perhaps more likely that this in an allusion to a pastoral erotic setting, such as Kṛșna's sport with the gopīs.

${ }^{175} \mathrm{We}$ feel that an adverb to the present participle is more apposite here than an obscure adjective ('bestower of essence') to the object, hence the emendation sādaram for sāradam.

${ }^{176}$ It would therefore seem that Mahāsukhavajra took the vocative putra with pibākṣobhyajalam. We modified the translation accordingly. 
Be grateful $^{177}$, O my dear, give me the pleasure born from the Vajra ${ }^{178}$ ! Look at my three-petalled Lotus, decorated in the middle with stamen. [6.52-53]

Grateful is one who recognises a favourable deed. This is the intended meaning: I have done you a favour by bringing you up; now you should return the favour! Born from the Vajra means [this:] Vajra means penis; [born from] means brought about by that. The meaning is [the pleasure] born from the churning of the Vajra [in the Lotus]. Three-petalled means triangular. [As for the compound ${ }^{179}$ ] beginning with middle: decorated in the middle with stamen, [that is to say] with a wick[-shaped] lump of flesh.

Oh, it is the field of Pleasureful Heaven adorned with the Red Buddha, giving pleasure to the lustful, utterly devoid of all conceptualisation. ${ }^{180}[6.54-55]$

[The particle] Oh (aho) here expresses pleasure. The [buddha-field] Pleasureful (Sukhāvatī) is so-called because it guards (avati), [that is to say] protects (rakșati), pleasure. That itself is a field, [i.e.] a place. Red [here] means blood; that itself is a buddha; [the Lotus] is adorned by that. The meaning is that the external [buddha]field [called] Sukhāvatī, too, is adorned by Amitābha[, who is red]. All conceptualisation means the conceptualisation of object, subject, and perception; [the Lotus] is devoid of that.

Alight on my reclining form; my mind trembles with desire. Place my two feet on your shoulder, and look me up and down. [6.56-57]

On [your] shoulder means on the two sides of the neck. Below means her vulva. Up means her face.

Then make the throbbing Vajra enter the opening in the centre of the Lotus. Give a thousand strokes, one hundred thousand, ten million, one hundred million, in my three-petalled Lotus, adorned with a wick of flesh ${ }^{181} \cdot[6.58-60]$

The throbbing vajra means the erect penis. A thousand strokes (dhāpa $\left.{ }^{\circ}\right)^{182}$ [: here] strokes [means] thrusts $\left({ }^{\circ} \bar{a} g h \bar{a} t a^{\circ}\right)$ [produced by] moving the hips; a thousand [of

${ }^{177}$ Rather than George's "gracious".

${ }^{178}$ We are more literal here than George's "the pleasure of the vajra".

${ }^{179}$ A very minor point, but we think that Mahāsukhavajra read madhyakiñjalka ${ }^{\circ}$ and not madhye kiñjalka ${ }^{\circ}$. Alternatively, consider his madhyetyādi an erroneous double sandhi.

${ }^{180}$ Instead of George's sentence, "Peace beyond all imagination, giving pleasure to the lustful."

${ }^{181}$ Although still slightly obscure, we opted for this rendering and not George's "bound round with flesh".

${ }^{182}$ It is noteworthy that this word does not occur in our standard dictionaries. Turner 1962-1966: 384, 'dhapp' no. 6729 lists a number of close meanings in Pañjābī, Kumāun̄ī, Oṛiyā, Hindī, and Nepālī, positing a possible Proto-Muṇạa derivation. The word is perhaps an onomatopoeic vernacular word Sanskritised by the anonymous author. Alternatively, it is possible that the word is a corruption of $d h \bar{a} y a$, in which case cf. Newar dhāyaldhāya (Jørgensen 1936: sub voce): 'to beat', 'to knock'. 
these], that is to say, many. This [i.e. a thousand] does not mean that one has to count them out [precisely]; and it should be understood that the same holds for one hundred thousand (lakșa $\left.{ }^{\circ}\right)^{183}$ and the other [numbers].

Insert your Vajra and propitiate your mind with pleasures ${ }^{184}$. Wow, wow! ${ }^{185}$ My Lotus is the essence of the essence, ${ }^{186}$ the very highest, and aroused by the tip ${ }^{187}$ of the Vajra, it is as red as the Banduka flower. ${ }^{188,}[6.61-63]$

[With the words] 'Wow, wow', [the consort] generates joy by praising [her Lotus]. The essence means pleasure and so on; ${ }^{189}$ [the Lotus is] the essence of that [essence], because of its [capability to bestow] Great Pleasure.

Concentrating on her speech, he should become motionless, with one-pointed mind. Without moving, he should meditate on the pleasure arising from that, with a fixed mind. Then he should answer her ${ }^{190}$ : "Wait a moment, my dear, that I may consider, for just a moment, your womanly form. [6.64-67]

Woman alone is the birth giver, the giver of true pleasure to the Three Worlds, the kind one. Those chattering fools engaged in evil action, who in this world ${ }^{191}$ disparage her out of hostility, will, by their action remain constantly tortured for three aeons in the fathomless ${ }^{192}$ Raudra Hell, wailing as their bodies burn in many fires. [6.68-71]

[Woman is here called] birth giver, for she generates pleasure. Kind means beneficial. Now, if one were to ask 'How is it that one goes to hell by disparaging women?', the following is stated. As everyone knows (kila), women generate thiswordly (i.e. common) pleasure. But [they] also [generate] otherworldly (i.e. soteriological) pleasure. For this very reason, they produce the utmost benefit[, since] they give birth to buddha[s], inasmuch as they have the nature of Prajñāpāramitā/the perfection of wisdom. For this very reason, by disparaging them, there will be great

${ }^{183}$ Although perhaps unusual for East Indian manuscripts, George’s lakșya ${ }^{\circ}$ does seem to be attested in this sense.

${ }^{184}$ Rather than George's "offer your mind with pleasure". This is perhaps an allusion to the Four Blisses.

${ }^{185}$ George translates "O Air, Air!", but this cannot be a vocative, which would have to be vāyo. The word is unusual, and we cannot find any parallels for it. Perhaps the meaning is more akin to English 'wow!'

${ }^{186}$ George is right to translate sārāt sāram simply as "quintessence", but we had to accommodate the commentator's gloss, hence the change.

${ }^{187}$ George has "top", presumably a misprint.

${ }^{188}$ Although ultimately it does not affect the meaning, we think that the more likely reading is raktabandhūka ${ }^{\circ}$.

${ }^{189}$ This is the result of a bold emendation, but we simply could not see any meaning in sāro mukhādikam.

${ }^{190}$ George's edition has tasmai for tasyai, but the translation is correct, therefore this must be a misprint.

${ }^{191}$ George's interpretation of iha is "now"; we disambiguated this.

192 The irregular lengthening of the second vowel in durāvagāha ${ }^{\circ}$ seeks to avoid breaking the metre. 
demerit. And because of that one will go to hell. As for the religious teaching (dharmo) of disparaging women (strinindā) proclaimed elsewhere, ${ }^{193}$ that is [intended] for beings unworthy [of the esoteric path] $\left(a b h a v y a^{\circ}\right)$, restricted to the body of this-worldly female lovers, and not for beings worthy [of the esoteric path] $\left(b h a v y a^{\circ}\right)$, who [use] the form of Prajñāpāramitā and other [goddesses to cultivate their] otherworldly female lovers. For it is impossible that an unworthy being should be able to superimpose the form of an otherwordly female lover onto a this-wordly female lover, even if told a hundred times. For they lack the expertise related to what should be avoided $\left(h e y a^{\circ}\right)$ and what should be adopted $\left({ }^{\circ}\right.$ upa $\left.\overline{d e y} a^{\circ}\right)$ [on the path]. And it is precisely for this reason that it is said:

I will teach [the Dharma] according to the particular dispositions of beings. ${ }^{194}$

On the contrary, one should proclaim the virtue[s] of women! Whether it is compassion encompassing all beings or protectiveness [encompassing all beings], it is [there] in the mind of women. ${ }^{195}$ Let us set aside [her] own people [for a moment]; she nourishes strangers with alms, too. If woman is so [i.e. has pity on all, protects all, nourishes all], then she is not different from Vajrayoginī. ${ }^{196}$ Let us set aside beholding her, and forget about her touch and embrace; even merely remembering her produces instant pleasure. ${ }^{197}$ All five objects of the senses are

${ }^{193}$ This is a reference to the what is sometimes referred to as aśucibhāvanāa, a fine example of which is Bodhicaryāvatāra $8.40 \mathrm{ff}$. (Steinkellner 1981: $96 \mathrm{ff}$.). Abhorring women is otherwise considered one of the fourteen basic trespasses (müläpattih) in tantric Buddhism, cf. Mūlāpattisamgraha 9ab (Lévi 1929: 266, 267): strīnām prajñāsvabhāvānām jugupsayā caturdaśì |; "Le quatorzième [scil. péché], c'est l'horreur des femmes, dont la nature propre est la Sapience."

${ }^{194}$ This is Mañjuśrīnāmasamgīti 1.15ab (Tribe 1994: 87, 230; we follow this translation with a slight modification). Although the invisible object there is the Litany (samgitith) itself, here Mahāsukhavajra silently expands the semantic range to the entire Dharma. Alternatively, construe sattvānām as a genitivus commodi (cf. Davidson 1981: 21), i.e. "I will teach [the Nämasamgitit/the Dharma] to beings, according to [their] particular dispositions."

${ }^{195}$ We conjectured ${ }^{\circ}$ parigrahā for ${ }^{\circ}$ parigrahah, and modified George’s translation: "On the contrary, one should say that women's merit encompasses all living beings. Whether it be kindness or protectiveness it must be in the mind of women." We do not see how merit could encompass all living beings, nor do we understand where 'must be' comes from.

${ }^{196}$ Here, too, we modify George's rendering: "Friend or stranger, she nourishes him with food. The woman who is like that is none other than Vajrayoginī." Note that nānyathā in the last pāda is unmetrical, it should be nānyā, since an Āryā versequarter cannot begin with long-short-long. That said, we should also note that the second $p \bar{a} d a$ is faulty and we are not sure how to remedy this, perhaps *bhikșayā hi puṣnạāti.

${ }^{197}$ Once again we modify George, since we suspect that he did not fully grasp the idiomatic expression (āstām ... dūrataḥ). He translates: "Be it her look, touch, or rub - when far away, the mere remembrance produces pleasure at that instant." We suspect that sprșțighrșțim is a corruption of the dual nominative sprșțighrșțī. We also disagree with translating ghrșțih as 'rub' in light of Mahāsukhavajra's gloss elsewhere (Ms 14v): kuru [...] ghrștim älinganacumbanādikam ity arthah |. 


\section{established in women in a divine form. ${ }^{198}$ Men, who take her as a wife, enjoy pleasure. [Ad 6.72-79]}

Take her as a wife means taking into wedlock.

Therefore, $O$ you who are faultless, adorned with all good qualities, $O$ Merit, ${ }^{199}$ Merit, Great Merit, favour me, $O$ Reverend Mother" [6.80-81]

[The woman is addressed as] Merit, because [she] is the cause of merit. The point is this: experiencing the gnosis of Great Pleasure is the cause for all merit, and the cause of that [experience] is none other than the consort (prajñ $\bar{a})$. For this reason it is taught:

Just like the fruit born of the vine is endowed with a flower, perfect awakening achieved $^{200}$ in a single moment is complete with the two equipments [of merit and knowledge]. ${ }^{201}$

${ }^{198}$ Here too we must disagree with George: "Woman, as object of the five senses, is endowed with a divine form."

${ }^{199}$ George translates this as "Purity".

${ }^{200}$ This is the result of a conjecture, which we explain in the next note.

${ }^{201}$ This is Cittaviśuddhiprakaraṇa 98 (Haraprasād Shāstrī 1898: 183; Patel 1949: 7; Varghese 2008: 252), but the verse was also incorporated into the Candamahāroṣanatantra, chapter 13 (30cd-31ab in Mical's numeration). It is also quoted in the Padmini (Ms 22r). The readings fluctuate wildly. The editio princeps has: yathā latāsamudbhütam phalapuṣpasamanvitam || yathaikakșaṇasambodhị sambhāradvayasamyutā |. Patel's edition (followed verbatim by Varghese) has yath $\bar{a}$ latā samudbhütā phalapușpasamanvitā | tathaikakșanasambodhih

sambhäradvayasamyutā $\|$. The best Ms of the Padminī has a reading which is much closer to ours: yathā latāsamudbhūtam phalam puṣpasamanvitam | tathaikalakșenasambodhih sambhäradvayasambhrtā $\|$. The closest match is that of the Candamahäroșanatantra itself. In Mical's draft edition we have the same forms as here, except ekakșañāc ca sambodhih for pāda c. We did check the manuscripts and found that ekakșanāc ca is indeed the reading of B (which, however, has phala ${ }^{\circ}$ ), as well as A, but in the latter this is the result of a correction, and ekaksanāt was the original reading. This hypometrical reading is what we found in Gt, too. Supposing that the original reading was metrical, we find it much more likely that ekakșanat is a corruption of ekaksanātta ${ }^{\circ}$, rather than ekakșanāc ca. Of course, it is equally likely that all these are simply corruptions of tathaikaksana $a^{\circ}$, the reading conjectured by Patel. However, it should be kept in mind that the attestation for Âryadeva's text is very weak indeed. As Patel himself says (1949: xii): "The original MS. of the work is of palm leaves in old Newari script. As it is very defective, its transcription and the printed text [scil. Haraprasād Śāstrī's 1898 editio princeps] based on it are not free from mistakes." We do not have access to this manuscript, but we checked the Baroda transcript, and it does not help us either: yathā latāsamudbhütam phalapușasamanvitam | yathaikakșnasambodhisambhāradvayasamyutam ||. We lack the botanical expertise to establish which version is more correct. Äryadeva's text seems to be saying that a vine appears together with both fruit and flower, in which case the vine is quick awakening, and its fruit and flower are the two equipments of merit (puny $a^{\circ}$ ) and knowledge (jñānasambhärah). However, the 
Then, look[ing] at her fixedly, he should press his lip with his teeth. Making a gasping sound, the yogī should make her naked. [6.82-83]

His lip means his own lip. ${ }^{202}$

He should perform the "Pleasure-Evoking" position, and the "Swing-Rocking
position," $[6.84]^{203}$

[The passage] beginning with He should perform the "Pleasure-Evoking" [position (bandham) $]^{204}$ is a brief outline (uddeśah),

Among those, ${ }^{205}$ in the middle of a bed, with the woman assuming the squatting seat, he should have her clasp her arms firmly together on his shoulders. [6.9091] ${ }^{206}$

[whereas the passage] beginning with Among those (tatra), [in the middle of a] bed is the elaboration (nirdeśah). All these [positions] should be demonstrated [by the master to the disciple $]^{207}$ with a pair of small dolls (puttalik $\bar{a}^{\circ}$ ) made of clay or beeswax.

Candamahāroṣanatantra and Mahāsukhavajra seem to think that the fruit born of the vine is already endowed with a flower. Judging by Mahāsukhavajra's argumentation just before the quotation, this would seem to mean that by cultivating wisdom ( prajñ $\bar{a}$, synonym for jūannam, but here punningly the consort, too), which is the cause of experiencing Great Pleasure, which in turn causes merit, one obtains the equipment of merit as well. If this is indeed his idea, it is certainly a somewhat unusual one. But the point perhaps is this: one needs to cultivate both equipments on the slower path, i.e. the päramitānaya, but in the case of quick awakening, i.e. the mantranaya, this is not the case. Also cf. Mahāsukhavajra to chapter 13 (Ms 30r): prajñopāyetyādinā suratayoga evaikasmin șat pāramitāh pūritā bhavanti | ata eva yogī śīghram buddhatvam prāpnute | stry eva prajñ̄āpāramitā niḩsvabhāvajñānajanikatvāt |, "The [passage] beginning with [from uniting] Wisdom and Means [teaches this:] the six Perfections [beginning with giving $\left(d \bar{a} n a^{\circ}\right)$ and ending in wisdom (prajñ $\left.\bar{a}^{\circ}\right)$ ] become completed in a single place, the yoga of intercourse. And it is as a result of this that the yogi achieves Buddhahood swiftly. The Perfection of Wisdom is none other than the woman, for she generates the gnosis of there being no own nature [in phenomena, persons, etc.]."

${ }^{202}$ It is difficult to see why this gloss is given when the meaning is very clear. Perhaps it is the case after all that the Ms's reading of the lemma, soștham, is correct?

${ }^{203}$ We skip the next five lines listing some more positions.

${ }^{204}$ The lemma makes it clear that 6.84 did not have a compound,

sukhodayabandham, as printed by George.

${ }^{205}$ This tatra is a partitive, and not "Then", as in George.

${ }^{206}$ We also skip the next lines up to 6.123 , with the exception of 6.109 which is glossed; these describe the positions in detail. These descriptions, as already noted by George (1974: 71, n. 65), are sometimes obscure and irrelevant for our article.

${ }^{207}$ It would have been appropriate to be a bit more verbose here. We must have a subject change, since it is highly unlikely that it would be the yogi demonstrating the positions to his partner with dolls, instead of actually performing them with her. 
[The words] Then [...] still with his left hand teach three things. $\dagger \ldots \dagger$ having introduced $\uparrow \ldots \uparrow$ the gesture of the sword without nails ${ }^{209}$ he should rub counterclockwise with the left [hand], then clockwise with the right [hand], until [the vulva] becomes moist. Then he should place his tongue in the middle of the lotus and perform cunnilingus for a few minutes with a loud licking movement while accepting with his head her [repeated installation of] the Three Syllables [with the accompanying gesture]. Then, with his left hand he should grasp the Vajra and insert it into the Lotus. It is by the word still (eva) that [all] this is taught, for particles have many meanings. Here the gesture of the sword [is this]: he should clench his left fist firmly and spread out his [joined] middle finger and ring finger.

He should kiss her mouth as much as he likes, again and again. Looking at her face after having lifted $i^{210}$, saying whatever words he likes, [6.124-125]

Saying words means [appellations which] intensify sexual desire, such as 'cow-girl' (gosvāmin̄ī). [These were explained before.]

he should suck her tongue, and drink the saliva of the mouth. He should eat the lipstick and waste of the teeth, meditating that it is pleasureful. And he should pinch the tongue gently with the teeth, and also the lips. [6.126-128]

Gently means slightly; the meaning [of this adverb] is that [he should pinch/bite her] in such a way that it does not cause pain $(\text { vyath } \bar{a})^{211}$.

With the tongue he should clean the holes of the nose, the corners of the eyes, and in-between the teeth; and he should eat all the waste produced from these

\footnotetext{
${ }^{208}$ We modified the translation, "with the right hand". First, we think savyena here means with the left - this enhances the antinomian nature of the act. Second, we needed something to reflect the particle eva, because of the commentator's unfortunately lacunose discussion.

${ }^{209}$ This should mean that the two pointed fingers in the sword gesture should have the nails cut short so as not to hurt the Lotus. A parallel passage (Ms 13r) suggests that here the yogī should excite his partner by stimulating two channels within the vagina: vidhāneneti padmāntargatasavyavāmapārśvavartinyor nāḍor (em., nādyo Ms) nirnakhamadhyamātarjanyañgulidvayena jihvayā vā cālanena $\mid[\ldots]$ prajñopāyākșaranam bhavati | tatah padmarandhram snigdham bhavati |; "Properly means by stimulating the two channels situated on the right and left side inside the Lotus either with the middle finger and the ring finger, the nails of which are cut short, or with the tongue. [...] Thence the aperture of the Lotus will become moist." We probably had something similar in the passage which is illegible here.

${ }^{210}$ This is what unnāmya means, not George's puzzling "lying down".

${ }^{211}$ We think that here 'pain' is intended, rather than 'damage', since slight wounds of lovemaking were not at all considered something to be avoided in love poetry and sexual guidebooks. Also cf. the next verse.
} 
[places]. ${ }^{212}$ He should kiss the forehead, eye, neck, ear, side, armpit, hand, and breast; and scratch ${ }^{213}$ them with the exception of the woman's two eyes. He should rub the nipple with the hand, suck, then bite. [6.129-133]

He should bite with the teeth. ${ }^{214}$

Having the woman lie on her back, he should kiss her lovely belly, remembering again and again, "Here was I formerly situated." He should touch the Lotus with

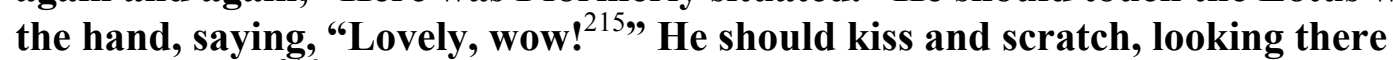
having pried it $^{216}$ with the hand. [6.134-137]

Having pried it means after having opened it (i.e. the Lotus).

Smelling the odour, he should clean with the tongue that hole of the woman. ${ }^{217}$ He should then say this kind of speech: "As I have entered through this, so too have I emerged numerous times." ${ }^{218}$ This path, which is straight as the nose, if practiced without Knowledge, would be the path to the six states of rebirth. But when practiced with Knowledge, it would be the Success of Cạ̣damahāroṣaṇa. [6.138-142]

Practiced without Knowledge means by serving it [i.e. the vagina of the consort] merely with thisworldly desire. Practiced with Knowledge means using it by serving it with otherwordly desire, as it is discussed [here].

Then, with sounds of 'sot' [issuing from his] mouth, ${ }^{219}$ he should eat the white

${ }^{212}$ We improved George's translation, which is "and the corners of the eyes. And he should eat all the waste produced from between the teeth."

${ }^{213}$ Rather than "pinch". We changed this throughout.

${ }^{214}$ As opposed to with the lips?

${ }^{215}$ See our note on vāyu to 6.62 above.

${ }^{216}$ We think this is what niṣkrșya means, not George's obscure "drawing down".

${ }^{217}$ This presumably means that he should extract the sexual fluids, which are then consumed in 6.143 .

${ }^{218} \mathrm{We}$ are not entirely sure that the words of the yogi do not extend up to the end of 6.142 , in which case 6.140a would be an intercalation in the direct speech.

Alternatively, perhaps he should only think/call to mind, as in 6.135, the line 6.139 and recite $6.138 \mathrm{~b}-142$.

${ }^{219}$ George's reading padmagatạ śvetam raktạ vā sukhasātkṛtaị̣ translated as "converting it entirely to pleasure, he should eat the white and red of the Lotus" is very clever, but we beg to disagree. In the notes (1974: 41), he records four manuscripts reading mukhasotkrtaih, and one more reading mukhasatkrtaih, probably a corruption of the former. Mahāsukhavajra doubtlessly read the same, although it is a little bit unusual that he does not include mukha ${ }^{\circ}$ in the lemma. We cannot find any derivation of sukhasātkr (i.e. a presumed analogue of agnisātkr or bhasmasātkr) anywhere in the literature, nor any parallels to the effect that the semen and the menstrual blood should be turned into sukham before consuming it at this stage. Mical opts for sukhasitkrtaih, which is again very clever, but the context is not primarily erotic anymore. That said, we could not find parallels for the onomatopoeic sound sot either. Mahāsukhavajra, however, makes it clear (after a small emendation) that this is 
and/or the red of the Lotus, while looking at her face again and again. [6.143144]

With sounds of 'sot' (sotkritaih) means with sounds of sipping in air with the mouth slightly open.

And, after scratching ${ }^{220}$ her thigh, he should rub her feet like a slave. He should place the Three Syllables on her forehead, [as well as] on her heart, accompanied with the gesture of a light fist. ${ }^{221}$ Then the yogi should perform concentratedly those positions, after the "Variegated" position. Then he should thrust as many times as he wishes, ${ }^{222}$ having his mind solely on pleasure. Optionally he may ejaculate or not. If he does ejaculate he should do so having his mind solely on pleasure. $^{223}[6.145-149]$

[Now for the passage] beginning with Optionally. Concerning this matter, a method to hold back ejaculation (aksarana ${ }^{\circ}$ ) is taught. When the Moon (i.e. semen) is able to reach up to the root of the jewel (i.e. the glans) at the end of [experiencing] Supreme Bliss, then [the practitioner] should contract the vital energy (vāyum) in the manner one holds back the urge to urinate, steadily (dhairyakramena) ${ }^{224}$ blocking the breath for a moment under the navel. The guru should teach this [to the disciple] by performing it himself. By this [method] there will be no ejaculation.

If he does [ejaculate], he should lick the Lotus on his knees. And he should eat with his tongue the white and read of the Lotus. And he should inhale it through a pipe in the nose, to increase his power. [6.150-152]

some kind of sipping sound (as one ingests the sexual fluids). As for 'of the Lotus', one should understand that 'the white' (i.e. semen) is not produced by the Lotus, it is only situated there at this stage, provided that the yogi has already ejaculated (which is described only in 6.149). If he has not, then we are dealing with another substance, which is also called 'white'. As Mahāsukhavajra says elsewhere (Ms 15r): śukram iti strīkāmadravam kevalam yogikṣaritarasasahitam vā|; "White means either the woman's fluid [born from] arousal only, or [the same] mixed with the juice ejaculated by the yogī." One should also note that George translated vā as 'and', which is perfectly possible. We would like to keep our options open.

${ }^{220}$ George's edition here probably contains a misprint, since sanakham should be a compound.

${ }^{221}$ We changed George's "and a light blow of the fist on her heart", because we find that here the kan suffix is meaningful. Cf. our note to 6.42 ; this is presumably where Mahāsukhavajra draws his interpretation from.

${ }^{222}$ We radically changed George's interpretation ("He should pay attention to that with desire"), after having consulted Ms Gt, which reads dhāpakạ̣ for dhyāyakam. For the meaning of this word, see 6.59 above.

${ }^{223}$ We changed George's translation: "he may secrete or not secrete, having his mind solely on pleasure". We find that 'secrete' is perhaps not the most fortunate choice here and we also think that he slightly misunderstood the point.

${ }^{224}$ That is to say, releasing and blocking repeatedly. The word dhairya ${ }^{\circ}$ is glossed elsewhere (Ms 13r) thus: dhairyety antarāntarā vajracālanaviśrāmeṇa paramānandasukham bhāvayed ity arthah |; "Steadily means repeatedly moving and resting the Vajra, he should contemplate the pleasure of Supreme Bliss." 
Beginning with [With] the nose, [the Lord] teaches another method. The point is this: sometimes he should lick the two substances $\left(d h \bar{a} t u^{\circ}\right)$ (i.e. menstrual blood and semen) of Wisdom (prajñ $\left.\bar{a}^{\circ}\right)$ and Means ( $\left.{ }^{\circ} u p \bar{a} y a^{\circ}\right)$ (i.e. the female and male practitioner) with his tongue. Sometimes he should draw [them] out from the Lotus with his mouth, place them in a vessel, insert a straw $(n \bar{a} l i k \bar{a} m)^{225}$, take note of his breath, ${ }^{226}$ and ingest it through his nostril, that is to say the aperture [beyond] the uvula (ghantika ${ }^{\circ}$ ). This is a synecdoche (upalakșanam), therefore other [methods] too should be observed. [For instance,] one should place in a vessel both the blood of a menstruating woman and semen extracted with the hand-consort (karamudra $\bar{a}^{\circ}$ ) (i.e. masturbation $)^{227}$; he should then mix them with the ring finger and ingest them by using a straw as explained before. Beginning with power, [the Lord] teaches the fruit of the procedure[s]. The meaning is this: by constantly performing [these] procedure[s], there will be a great increase in the yogî’'s strength, inasmuch as he will stop wrinkling, greying, and [even] death.

After washing the Lotus with the tongue, he should have Wisdom stand up and he should kiss her. And, after having taken her on his lap, ${ }^{228}$ he should eat meat and fish. He should drink milk or wine, in order to increase his desire. ${ }^{229}$ After

${ }^{225}$ George's choice, nalik $\overline{\mathbf{a}}^{\circ}$, is perfectly justified, but $n \bar{a} l i k \bar{a}$ is perhaps more common. We left 'straw' in the translation, but this could be any kind of tube. ${ }^{226}$ This expression alludes to chapter 22 of the Candamahärosanatantra, the vāyuyogapatala, which teaches techniques for the manipulation of winds (i.e. vital energies) through the subtle channels of the body.

${ }^{227}$ These two options for ejaculation are also mentioned by Mahāsukhavajra in his commentary to chapter 13 (Ms 29v): tatra rāganāśopadeśo vajrapadmasamyogena śukrakșaranam karamudraya $v \bar{a} \mid$; "Among these, the teaching to quell passion [refers to] ejaculating semen either by means of uniting the Vajra and the Lotus, or by means of the hand-consort." Another expression for karamudrā used by this author is karasundarī (Ms 32r). Masturbation without ejaculation is not mentioned, but it is attested in the Kālacakra corpus, which usually advocates seminal retention in sexual yoga, e.g. Raviśrījñāna's Gunabharaṇī to a verse from the Laghukālacakratantra (5.121) incorporated into Anupamarakșita's Șadañgayoga (Sferra 2000: 115, 280): atha bimbadvāreṇa nānandasukham bhavati, tadā padme vajradhvanir vā śanakaih kartavyaḥ | atha strī na labhyate, tadā svakarakamalenollālanam kartavyạ̣ saukhyavrddhihetoh pätahetor na |; "Or, if there is no pleasure of Bliss by means of

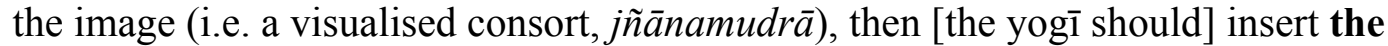
Vajra Thunder (i.e. the penis) into the Lotus slowly. Or, if a woman (i.e. a karmamudrā) cannot be obtained, then he should fondle [his penis] with the Lotus of his own hand, in order to intensify pleasure, but not for ejaculation."

${ }^{228}$ Here we changed George's "after hugging her". Drinking and eating are done by both, in spite of the singular. In fact, a line in the next chapter (7.8) explains that the woman should eat first, and the man should eat her leftovers (George 1974: 31, 78). ${ }^{229}$ This should be done in moderation, only to the extent that it achieves the desired effect. Mahāsukhavajra is against excessive drinking because it affects concentration and not because it is inherently sinful (Ms 29r): na hi madyapānamātram pāpāvāhakam, jalādipāne 'pi tathā prasañgāt | kim tu madajanakatvam eva tasya virūpakam, tac ca nālpapānena bhavati | vistarapānena tu vikșepaḥ sambhāvyate | vikșepāc ca pāpakarmasambhāvanā syāt |; "Surely, it is not drinking liquor per se 
his fatigue has decreased, ${ }^{230}$ he should desire with pleasure, etc. And, in the foregoing manner, the couple should begin again with each other. By this repeated practice, Great Bliss is attained, and in this very lifetime the practitioner gains the state of Caṇdamahāroṣaṇa. ${ }^{231}[6.153-159]$

Attained means [that Great Bliss will be] present continously, day and night. He gains, [i.e.] he achieves, the state of Caṇda[mahā]roṣaṇa ${ }^{232}$ [i.e.] the achievement of the Great Seal. In this very [lifetime] means in the present incarnation.

I have disclosed this practice for the sake of giving Success to the lustful. [6.160]

To the lustful means to desirous ones. The implication is that for those who are without desire, there will be Awakening after three Uncountable Aeons (trikalpāsamkhyeyena) through the procedure of the mode of perfections (pāramitānaya) (i.e. exoteric Buddhism, the non-tantric Mahāyāna). ${ }^{233}$ Because of their numerous doubts (vicikits $\bar{a}^{\circ}$ ), they do not have faith (śraddhā) in this teaching (dharme). But even desirous ones who lack faith will not succeed, nor will there be Success by having faith in any other practice than this. For if one desires ghee, one should not churn water, but curd or milk. For it is only there that [ghee] can be found †and $\uparrow^{234}$ because of the nature of the [inherent] power of things (vastuśakti ${ }^{\circ}$.

${ }^{235}$ Placing the soles of the feet on the ground, with the legs bent and making an oblique angle between them, this is known as the "Half-moon" seat, which gives the pleasure of desire. [6.169-170]

Obliquely stretched out means the [the two legs] like the wings of a duck.

Again, having her assume the "Bow" seat, he should have his face fall in the middle of her anus. He should also stroke her anus with his nose. [6.177-178]

Also with his nose means he should breathe in the odour after having placed his nose

which brings about sin, for we would have the absurd consequence that the same applies to drinking water and so on; its impropriety comes from causing intoxication, but that does not happen if one drinks moderately. However, drinking excessively might result in distraction, and distraction in turn may cause sinful acts."

${ }^{230}$ We find the form jiryati somewhat strange. Perhaps we should understand it to be a finite verb and not a locative present participle, in which case we must emend śrame to śramam.

${ }^{231}$ We think this interpretation more likely than George's "title of Canḍamahāroșana".

${ }^{232}$ Mahāsukhavajra's lemma is at first glance hypermetrical. However, in this register it is perfectly possible that the reading is original and that it was pronounced

*candaroṣ 'na .

${ }^{233}$ The 'Uncountable' is, in spite of its name, an actual number. On the various ways in which it is calculated, see Yong 2008.

${ }^{234}$ We find the ca disturbing, because vastuśaktisvābhāvya is not an additional reason but the technical designation of what was just explained.

${ }^{235}$ We skip lines 6.161-176, with the exception of 6.169-170, which are glossed. This passage deals with various postures (paryainkam) and seats (äsanam). 
there.

He should contemplate the pleasure produced by that in [meditative] union [with Caṇda[mahā]roṣaṇa. ${ }^{236}$ Then the yogĩ should be ${ }^{237}$ liberated, with all predilections abandoned. [6.179-180]

[Meditative] union [with] Caṇḍa[mahā]roṣaṇa means an unwavering absorption. Liberated means liberated from suffering, for [he will] have a form of Supreme Bliss.

Making his mind devoid of aversion, he should make love to his mother ${ }^{238}$. By following lust, merit is obtained; from aversion demerit accrues. [6.181-182]

[His] mother means the consort defined above. Demerit means sin.

There is no greater evil than aversion, no greater merit than pleasure. ${ }^{239}$ And therefore $^{240}$ he should concentrate upon the pleasure arising from desire. [6.183184]

Then the Lady joyfully paid homage to the Lord, and praising him said this: [6.185-186]

O Lord, is this means of Success for human beings only, or is it for others, also? [6.187-188]

The Lord said: [6.189]

Those beings situated in all directions who are devoted to this, gods, demons, men, and nāgas, too, ${ }^{241}$ succeed as practitioners. [6.190-191]

Then, when they heard that, the gods, Maheśvara, etc., taking the goddesses Gaurī, Lakșmī, Śacī, Ratī, etc., began to meditate. Then all of them, at that moment, at that minute, in that hour obtained the state of Canda[mahā]rosana and roamed the earth. ${ }^{242}$ There, ${ }^{243}$ Maheśvara succeeded, by the name of ${ }^{244}$

\footnotetext{
${ }^{236}$ We changed George's translation, "He should concentrate that the Pleasure produced by that is from the joining with Caṇuamahăroṣana." First, we do not think that 'pleasure' here has any technical meaning, therefore capitalisation is not required. Second, George took the tasil suffix as an ablative, but this is not always the case. ${ }^{237}$ Or simply 'is/will be'.

${ }^{238}$ George's mātrām must be a misprint.

${ }^{239}$ George (1974: 77, n. 70) voices a certain uneasiness concerning his interpretation of virägah as 'aversion' rather than 'absence of lust'. We fully sympathise with this, but prefer the latter perhaps a little bit more.

${ }^{240}$ Rather than "then".

${ }^{241}$ We changed George's ungrammatical "who are devoted to this. Gods, demons, men, and Nāgās (sic!), too,". In light of the question it is somewhat suspicious that men (i.e. humans) are mentioned again.

${ }^{242}$ We changed George's translation in light of the commentary. He has "Then, at that instant, all of them, just at that very moment obtained the title of Caṇuamahāroṣaṇa and roamed the earth." Mahāsukhavajra's lemma tanmuhūrtam lacks the kan suffix.
} 
Vajraśańkara; Vāsudeva as Vajranārāyaṇa; Devendra as Vajrapāṇi; and Kāmadeva as Vajrānanga. Those led by these principal ones, ${ }^{245}$ godlings succeeded equal in number to the sands of the Ganges River. [6.192-196]

At that moment refers to the fact that a superior kind of being (adhimatra ${ }^{\circ}$ ) understands reality already in the moment of Bliss $\left(\bar{a} n a n d a^{\circ}\right)$. At that minute refers to the fact that an advanced being $\left(m a d h y a^{\circ}\right)$ understands reality already in the moment of Supreme Bliss (paramānand $a^{\circ}$ ). In that hour refers to the fact that a beginner $\left(m r d u^{\circ}\right)$ understands reality only in the moment of Innate Bliss (sahajānand $a^{\circ}$ ), in between [the moments of] having achieved Supreme Bliss and entering the Bliss of Cessation. ${ }^{246}$

[Now I shall] explain the forms of Vajraśankara and the others. Among these, Vajraśankara has two arms and one face, he is white-coloured, wears a tiara [holding together his] dreadlocks, he is without adornments, [except] the five mudrās, [and] his body is smeared with ash, ${ }^{247}$ he is three-eyed, with his left [hand] he holds a skull bowl [with] a skull staff ( ${ }^{\circ} k$ hatvāing $\left.a^{\circ}\right)$ [propped against his left shoulder], with his right [hand] he holds a rattle-drum (damaru ${ }^{\circ}$ ), he is sitting cross-legged, mounted on a bull; he is embraced by Vajragauri, who has the colour of molten gold, is adorned with various kinds of ornaments, and is sixteen years old; in her left hand she

Note, however, that if we leave it, the passage from atha to mahitale is almost metrical: $p \bar{a} d a$ a is faulty, unless one reads it with some kind of shwa sound/glottal stop between $\mathbf{t a t}^{\circ}$ and ${ }^{\circ} \mathbf{k s a n a m} ; p \bar{a} d a b$ is fine, if we retain the kan; $p \bar{a} d a c$ should be pronounced with ${ }^{\circ}$ roṣ' $^{\prime} \mathbf{a}^{\circ}$, which is not unprecedented in this chapter, cf.

Mahāsukhavajra's lemma of 6.159; and pāda $d$ is again fine.

${ }^{243}$ Or perhaps understand tatra as a partitive, 'among them'.

${ }^{244}$ Or perhaps 'as/qua'; the same would apply to the others, too.

${ }^{245}$ We modified George's interpretation, "In the same way as these principal ones".

${ }^{246}$ Mahāsukhavajra's view on how the Blisses are experienced in lovemaking is given in the commentary to the first chapter (Ms 3r). Bliss (anandah) allows for a small amount of pleasure, experienced during foreplay, up to the moment of penetration. Supreme Bliss (paramānandah) is a greater degree of pleasure, experienced during the actual coitus, up to the moment of semen reaching the root of the glans. Innate Bliss (sahajānandah) is a supreme kind of pleasure, devoid of the concepts of subjectobject-perception, that is to say, non-conceptual, which happens during the time semen travels from the root of the glans into the vagina. The Bliss of Cessation (viramānandah) is again conceptual, experienced after ejaculation, when the yogì, after a few moments of stillness realises 'I have experienced pleasure' (sukham bhuktam mayā). A short ancillary teaching (upadeśah) on the various points the yogi should direct his attention to during these moments is given in the commentary to chapter 3 (Ms 11r). Mahāsukhavajra then sides with what Isaacson \& Sferra call "position A" regarding the order of Blisses, the other, "position B" being that sahajānandah is the fourth and viramānandah, possibly in a different sense (i.e. not 'cessation'), is the third (2014: 96-100).

${ }^{247}$ The five $m u d r \bar{a}$ s are the kāpalika bone-accoutrements, which are signs of that observance; the ash is the sixth (English 2002: 158-159). The five (chaplet, earrings, necklace, armlets, girdle) are listed i.a. in the Hevajratantra I.viii.17 (Snellgrove 1959: 26), where they equated with the Tathāgatas; the precise correspondence is given in Hevajratantra I.vi.11-12ab (Snellgrove 1959: 18). 
holds a red lotus. Vajranārāyaṇa is mounted on Garuḍa, he is four-armed, dark blue, has a jeweled tiara, he is adorned with various adornments, he is seated cross-legged, with his two right hands, which are raised, he holds a jewel and a mace, in his two left hands, which are [also] raised, he holds a conch shell and a discus; he is embraced by a Vajralakṣmī, who is white [but otherwise] similar to Vajragaurī. Vajrapāṇi has two arms, a thousand eyes, wears a jeweled tiara, bears various adornments, has the colour of gold, with his right [hand] he holds a vajra, with his left [hand] he points his index finger threateningly $\left(\operatorname{tarjan} \bar{\imath}^{\circ}\right.$ ), he sits cross-legged, mounted on [the elephant called] Airāvana; he is embraced by Vajraśacī who is similar to Vajragaurī. Vajrānanga is mounted on a flying palace $\left({ }^{\circ}\right.$ vimanna $\left.{ }^{\circ}\right)$ with dolphin $\left(\right.$ makara $\left.^{\circ}\right)$ faces on it, seated cross-legged, has two arms and one face, [wears] a jeweled tiara, is embellished with various ornaments, and is yellow-colored; in his right [hand], he holds an arrow, in his left, a flower bow; he is embraced by Vajrarati ${ }^{248}$, who is similar to Vajragaurī. Among these, Maheśvara bears Amitābha on his head [in addition to] wearing a crescent moon. Vāsudeva holds Akṣobhya on his head. Indra holds Ratnasambhava on his head. Kāmadeva has Amitābha on his head. ${ }^{249}$ Those led by these Iprincipal deities] [denotes minor deities] such as Vajrakārttika and Vajragaṇapati.

\section{Endowed with the five objects of desire, acting for the benefit of all beings, all these beings, having various corporeal forms are conquerors in disguise. ${ }^{250}$ [6.197-198]}

[As for the verse] beginning with Five: the five objects of desire (kāmāh) are sight, taste, touch, sound, and smell. They are called so $(k \bar{a} m \bar{a} h)$, because they are desired (kāmyante), [that is to say,] wanted. The word guna $\bar{h} h$ is affixed to them, because they are repeated (gunyante), [that is to say,] reiterated (i.e. desired again and again). [Beings (bhūtāh $)]$ are [endowed ( ${ }^{\circ}$ upetāḥ) with them, that is to say,] conjoined with them.

Just as the lotus, which emerges from the mud, is not smeared by defilements of $^{251}$ the mud, likewise are they not smeared by defilements who are produced by the method of Lust. [6.199-200]

Beginning with Just as, [the Lord] explains the [inherent] power of things. Defilements refer to the colour, smell, etc. of the mud, [i.e.] of the mire.

\footnotetext{
${ }^{248}$ We conjectured that this goddess also has the prefix vajra ${ }^{\circ}$ to her name.

249 This is otherwise called 'sealing' (mudranam). The Tathāgatas act as 'family chieftains' (kulapatayah), and by adding them on the heads of other deities, their overlordship is displayed. We find it somewhat odd that the Tathāgata of paramount importance, Vairocana, is missing. The absence of Amoghasiddhi, while problematic, is perhaps less puzzling.

${ }^{250}$ We reformulated slightly George's translation, “Although involved with the desirous objects of the five senses, they act for the benefit of all beings. All these beings, having various corporeal forms, although in fact illusory, are conquerors." $\mathrm{He}$ also prints the translation of 6.197 with the prose before. We do not think that māy $\bar{a}$ vin means that the beings themselves are illusory, but that they themselves project illusion, like magicians. If this is the case, the beings (bhūtāh) are the gods mentioned in the prose section before.

${ }^{251}$ George has "in"; we translate more literally.
} 
Thus ends the sixth chapter, concerning the Yoga of the Perfected Stage, in the Reverend Caṇdamahāroṣaṇa Tantra, called the Sole ${ }^{252}$ Hero. [6.201-202]

The chapter [is called the chapter of the perfected stage, because] it has as its chief topic $^{253}$ the Yoga of the Perfected [Stage].

Thus [ends] the commentary of the sixth chapter.

${ }^{252}$ George prints ekala ${ }^{\circ}$ for the more common form, ekalla ${ }^{\circ}$.

${ }^{253}$ We emended here to ${ }^{\circ}$ pradhānah in spite of the overwhelming evidence to the contrary. Of the surviving chapter-colophons, sixteen have ${ }^{\circ}$ pradhanam, and only three ${ }^{\circ}$ pradhānah (one being the result of a correction). Chapter 2 has ${ }^{\circ}$ pradhānatvāt. 


\section{Bibliography}

\section{Unpublished}

Caṇdamahāroṣanatantra - draft critical edition by Wiesiek Mical from (A) Royal Asiatic Society London, Hodgson no. 46, ff. 46 palm-leaf, incomplete, undated, ca. 14th c.; (B) National Archives Kathmandu 3-687 = Nepal-German Manuscript Preservation Project A 994/4, ff. 48 palm-leaf, complete, dated Nepālasamvat $547=$ 1427 CE; (Gt) Niedersächsische Staats- und Universitätsbibliothek Göttingen, Xc 14/43-45, ff. 47 palm-leaf, incomplete, undated, perhaps 13th or 14th c.; and the Padmāvatī Ms.

Cittaviśuddhiprakaraṇa - (Baroda transcript) Oriental Institute Baroda, Acc. No. 13288, ff. 6 paper, incomplete, undated, modern.

Padmin̄̄ - (Ms) Buddhist Library Nagoya, Takaoka CA 17, ff. 49 paper, complete, dated Nepālasamvat $762=1642$ CE.

Mahāmudrātilaka - (Ms) draft critical edition by Péter-Dániel Szántó from the codex unicus, Staatsbibliothek zu Berlin, Preußischer Kulturbesitz Orientabteilung Hs. or. 8711, ff. 57 paper, complete, dated Nepālasamvat $947=1827 \mathrm{CE}$ from an exemplar dated Nepālasamvat $324=1204 \mathrm{CE}$.

\section{Editions, studies, reference works}

Bhattacharya 1925 - Benoytosh Bhattacharya, Sādhanamālā Vol. I. Gaekwad's Oriental Series No. 26, Oriental Institute, Baroda.

Bhattacharya 1928 - Benoytosh Bhattacharya, Sādhanamālā Vol. II. Gaekwad's Oriental Series No. 41, Oriental Institute, Baroda.

Chandra 1981 - Lokesh Chandra, Abhidhānottara-Tantra: A Sanskrit Manuscripts from Nepal reproduced by $\sim$ from the Collection of Prof. Raghuvira. Śata-pitaka Series: Indo-Asian Literatures Volume 263, New Delhi.

Chazot, Chazot \& Delamotte 2015 - Eric Chazot, Pascal Chazot, Evelyne Delamotte, Le Tantra de Chandamahârosana. Éditions du Rocher, Monaco.

Csoma de Körös 1836-1839 - Alexander (Sándor) Csoma de Körös, "VII. Analysis of the Gyut Ka-Na," Asiatic Researches. 359-388.

Davidson 1981 - Ronald M. Davidson, "The Litary of Names of Mañjuśrī: Text and Translation of the Mañjuśrīnāmasamgīti," Michel Strickmann (ed.), Tantric and Taoist Studies in Honour of R. A. Stein. Vol. I, Mélanges Chinois et Bouddhiques 20, Institut Belge des hautes études chinoises, Bruxelles, 1-69.

Deshpande 1986 - M.N. Deshpande, The Caves of Panhāle-Kāji (Ancient Pranālaka): An art historical study of transition from Hinayana, Tantric Vajrayana to Nath Sampradaya (third to fourteenth century A.D.). Memoirs of the Archaeological Survey of India, No. 84. Archaeological Survey of India, New Delhi. 
DhTC 2016 - The Dharmachakra Translation Committee at http://read.84000.co/\#UT22084-080-015/title

English 2002 - Elizabeth English, Vajrayoginī: Her Visualizations, Rituals, \& Forms. A Study of the Cult of Vajrayogini in India. Studies in Indian and Tibetan Buddhism, Wisdom Publications, Boston.

Fan 2011 - Muyou Fan, Advayasamatāvijaya: A Study Based upon the Sanskrit Manuscript Found in Tibet. Series of Sanskrit Manuscripts \& Buddhist Literature 2, Research Institute of Sanskrit Manuscripts \& Buddhist Literature, Beijing.

Farrow \& Menon 1992 - G.W. Farrow \& I. Menon, The Concealed Essence of the Hevajra Tantra. Motilal Banarsidass Publishers, Delhi.

Ferguson 2010 - Anthony Ferguson, The Sex Doll: A History. McFarland \& Company, Jefferson NC/London.

Gäng 1981 - Peter Gäng, Das Tantra des Grausig-Groß-Schrecklichen. Stechapfel Verlag, [West] Berlin.

George 1971 - Christopher S. George, The Candamahäroṣaṇa Tantra, Chapters IVIII. Doctoral dissertation, University of Pennsylvania.

George 1974 - Christopher S. George, The Candamahāroșana Tantra, Chapters IVIII: A Critical Edition and English Translation. American Oriental Series volume 56, American Oriental Society, New Haven, Connecticut.

Ghosh 1938 - Manomohan Ghosh, Pāṇinūya-Śikșā or the Śikșā-vedanga [sic!] ascribed to Pānini (being the most ancient work on Indo-Aryan Phonetics). Critically edited in all its Five Recensions with an Introduction, Translation and Notes together with its two Commentaries. University of Calcutta, Calcutta.

Gopal 1989 - Lallanji Gopal, The Economic Life of Northern India, c. A.D. 700 1200. Second, revised edition. Motilal Banarsidass Publishers, Delhi.

Haraprasād Shāstrī 1898 — Mahāmahōpādhyāya Haraprasād Shāstrī, "The discovery of a work by Āryadēva in Sanskrit," Journal of the Asiatic Society of Bengal Vol. LXVII. Part I, pp. 175-184.

Hara Prasad Śāstri 1915 - Mahamahopādhyaya Hara Prasad Śāstri, Catalogue of Palm-leaf \& Selected Paper MSS. Belonging to the Durbar Library, Nepal, Vol. II. Baptist Mission Press, Calcutta.

Hartzell 2012 - James F. Hartzell, "The Buddhist Sanskrit Tantras: "The Samādhi of the Plowed Row"," Pacific World: Journal of the Institute of Buddhist Studies 3/14, 63-178.

Isaacson \& Sferra 2014 - Harunaga Isaacson \& Francesco Sferra, The Sekanirdeśa of Maitreyanātha (Advayavajra) with the Sekanirdeśapañjikā of Rāmapāla, Critical 
Edition of the Sanskrit and Tibetan Texts with English Translation and Reproductions of the MSS. Manuscripta Buddhica 2, Asien-Afrika-Institut Universität Hamburg \& Università Degli Studi di Napoli “L'Orientale”, Napoli.

Jørgensen 1936 - Hans Jørgensen, A Dictionary of the Classical Newārī. Historiskfilologiske meddelelser 23/1, Levin \& Munksgaard, København. Reprint: Tiwari's Pilgrims Book House, Kathmandu, 1989.

Kuranishi 2016 - Kenichi Kuranishi, "A Study on Scholarly Activities in the Last Period of the Vikramaśîla Monastery: Quotations in Ratnarakșita's Padminī," Oriental Culture no. 96, 49-61.

La Vallée Poussin 1897 — Louis de La Valée Poussin, "The Buddhist "Wheel of Life" from a New Source," Journal of the Royal Asiatic Society of Great Britain and Ireland (new series) 29, 463-470.

Lévi 1929 - Sylvain Lévi, “Autour d'Aśvaghoṣa,” Journal Asiatique 215, 255-285.

Luo 2010 - Luo Hong, The Buddhakapālatantra Chapters 9 to 14 Critically edited and translated. Sanskrit Texts from the Tibetan Autonomous Region no. 11. China Tibetology Publishing House/Centre for Tantric Studies (AAI), Beijing/Hamburg.

Pandey 1997 - Janardan Pandey (ed.), Bauddhalaghugranthasañgraha. Rare Buddhist Texts Series 14, Central Institute of Higher Tibetan Studies, Sarnath, Varanasi. [The Sanskrit Text was first published in Dhīh 21 (1996): 129-149.]

Patel 1949 - Prabhubhai Bhikhabhai Patel, The Cittaviśuddhiprakarana of Aryadeva: Sanskrit and Tibetan Texts. Visva-Bharati, [Shantiniketan].

Petech 1984 - Luciano Petech, Mediaeval History of Nepal (c. 750-1482). Second, thoroughly revised edition. Serie Orientale Roma LIV, Istituto Italiano per il Medio ed Estremo Oriente, Roma.

Samdhong Rinpoche \& Dwivedi 1988 - Samdhong Rinpoche \& Vrajvallabh Dwivedi (eds.), Guhyādi-Aștasiddhi-Sangraha. Rare Buddhist Texts Series 1, Central Institute of Higher Tibetan Studies, Sarnath, Varanasi.

Samdhong Rinpoche \& Dwivedi 1990 - Samdhong Rinpoche \& Vrajvallabh Dwivedi (eds.), Dākinījālasamvararahasyam [sic!] By Anañgayogī. Rare Buddhist Texts Series 2, Central Institute of Higher Tibetan Studies, Sarnath, Varanasi.

Sāmbaśiva Śāstrī 1926 — Sāmbaśiva Śāstrī (ed.), The Mímāmsāślokavārtika with the Commentary Kāśikā of Sucaritamiśra, Part I. Trivandrum Sanskrit Series no. XC/Śrī Setu Lakṣmī Prasādamālā no. II, University of Travancore, Trivandrum.

Sanderson 2009 - Alexis G. J. S. Sanderson, "The Śaiva Age—The Rise and Dominance of Śaivism During the Early Medieval Period," in Shingo Einoo (ed.), Genesis and Development of Tantrism. Institute of Oriental Culture Special Series 23, Institute of Oriental Culture, University of Tokyo, 41-349. 
Sferra 2000 - Francesco Sferra, The Șadaingayoga by Anupamarakșita with Raviśrījñ̄ana's Gunabharañināmașadaingayogatippañi: Text and annotated translation. Serie Orientale Roma LXXXV, Istituto Italiano per L'Africa e L'Oriente, Roma.

Shukla Shastri 1994 - Babulal Shukla Shastri (ed.), Mahamati Padmashri's Nāgar Sarvawam With Jagadjyotirmall's Sanskrit and Pandit Babulal Shukla Shastri's Anāvilā Hindi Commentary. Eastern Book Linkers, Delhi.

Snellgrove 1959 - D.L. Snellgrove, The Hevajra Tantra: A Critical Study, Part 2: Sanskrit and Tibetans Texts. London Oriental Series volume 6, Oxford University Press, London.

Steinkellner 1981 — Ernst Steinkellner, Śāntideva: Eintritt in das Leben zur Erleuchtung (Bodhicaryāvatāra): Lehrgedicht des Mahāyāna aus dem Sanskrit übersetzt. Eugen Diederichs Verlag, Düsseldord-Köln.

Sugiki 2002 - Tsunehiko Sugiki, "A Critical Study of The Vajraḍākamahātantrarāja (I) - Chapter. 1 and 42.-,", The Chisan Gakuho/Journal of Chisan Studies no. 65, 81-115.

Szántó 2012 - Péter-Dániel Szántó, Selected Chapters from the Catuspițthatantra, Vol. I Introductory study with the annotated translation of selected chapters. Vol. II Appendix volume with critical editions of selected chapters accompanied by Bhavabhatta's commentary and a bibiography. Doctoral dissertation, University of Oxford.

Szántó 2016 - Péter-Dániel Szántó, "Before a Critical Edition of the Sampuṭ," Zentralasiatische Studien 45, 397-422.

Thakur 1957 - Anantalal Thakur (ed.), Ratnakīrtinibandhāvalī (Buddhist Nyāya Works of Ratnakirti). Tibetan Sanskrit Works Series Vol. III, Kasiprasad Jayaswal Research Institute, Patna.

Tribe 1994 - A.H.F. Tribe, The Names of Wisdom: A Critical Edition and Annotated Translation of Chapters 1-5 of Vilāsavajra's Commentary on the Nämasamgīti, with Introduction and Textual Notes. Doctoral dissertation, University of Oxford.

Tripathi \& Negi 2006 - Ram Shankar Tripathi \& Thakur Sain Negi (eds.), Hevajratantram With Yogaratnamālāpañjikā of Mahāpanditācārya Kṛ̦napāāa. Bibliotheca Indo-Tibetica Series 65, Central Institute of Higher Tibetan Studies, Sarnath, Varanasi.

Turner 1962-1966 - A Comparative Dictionary of the Indo-Aryan Languages. Oxford University Press, London.

van der Kuijp 2009 - Leonard W. J. van der Kuijp, "On the Vicissitudes of Subhūticandra's Kämadhenu Commentary on the Amarakoșa in Tibet," Journal of the International Association of Tibetan Studies 5, 1-105. 
Varghese 2008 - Mathew Varghese, Principles of Buddhist Tantra: A Discourse on Cittaviśuddhi-prakarana of Āryadeva. Munshiram Manoharlal Publishers, New Delhi.

Yong 2008 - Bhiksu Jin Yong, "How Large is One Asamkhyeya," Vajra Bodhi Sea $462,42-44$. 